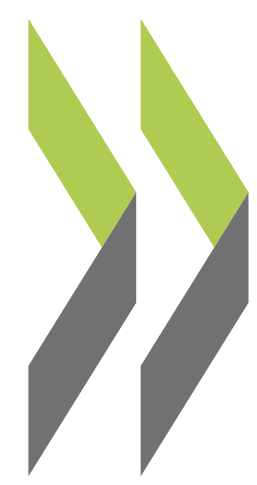

OECD Economics Department Working Papers No. 597

Monetary Policy, Market Excesses and Financial Rudiger Ahrend, Turmoil Robert Price 
Organisation de Coopération et de Développement Économiques

Organisation for Economic Co-operation and Development

10-Mar-2008

ECONOMICS DEPARTMENT

English text only

MONETARY POLICY, MARKET EXCESSES AND FINANCIAL TURMOIL

ECONOMICS DEPARTMENT WORKING PAPER No. 597

By

Rudiger Ahrend, Boris Cournède and Robert Price

All Economics Department Working Papers are available through OECD's Internet web site at www.oecd.org/Working_Papers

JT03242013

Document complet disponible sur OLIS dans son format d'origine

Complete document available on OLIS in its original format 


\section{ABSTRACT/RÉSUMÉ}

\section{Monetary policy, market excesses and financial turmoil}

This paper addresses the question of whether and how monetary policy ease may lead to excesses in financial and real asset markets and ultimately result in financial dislocation. It presents evidence suggesting that periods when short-term interest rates have been persistently and significantly below what Taylor rules would prescribe are correlated with increases in asset prices, especially as regards housing, though no systematic effects are identified on equity markets. Significant asset price increases, however, can also occur when interest rates are in line with Taylor rules, associated with periods of financial deregulation and/or innovation. The paper argues that accommodating monetary policy over the period 2002-2005, in combination with rapid financial market innovation, would seem in retrospect to have been among the factors behind the run-up in asset prices and consequent financial imbalances -- the (partial) unwinding of which helped trigger the 2007 financial market turmoil. Moreover, the paper points out that in certain situations policy rates may be a rather blunt tool for dealing with both the build-up and aftermath of financial imbalances, raising the question whether "macro-prudential" regulation could be useful.

JEL codes: E44, E5, F3, G15

Keywords: interest rates; monetary policy; housing; sub-prime crisis; financial markets; macro-prudential; regulation; Taylor rule; house prices; asset prices; financial imbalances; market turmoil; financial innovation

$$
* * * * *
$$

\section{Politique monétaire, excès des marchés et troubles financiers}

Dans quelle mesure la politique monétaire a-t-elle pu conduire à des excès dans les marchés d'actifs réels et financiers et in fine mener aux récentes perturbations financières ? Cette étude aborde cette question en fournissant des éléments qui laissent à penser que, lorsque les taux courts se trouvent de manière durable nettement au-dessous de ce que prescrirait une règle de Taylor, les prix des actifs, notamment immobiliers, ont tendance à s'élever (hormis ceux des actions). D'importantes augmentations des prix des actifs sont aussi observées lors des périodes de dérégulation ou d'innovation financières. Cette étude avance des arguments selon lesquels le relâchement monétaire observé en 2002-2005, se combinant à une rapide innovation financière, apparaît rétrospectivement comme l'un des facteurs ayant contribué à l'envolée des prix des actifs et au gonflement des déséquilibres financiers qui en a résulté, un processus dont la résorption a alimenté les troubles financiers de 2007. En outre, cette étude souligne que, dans certaines situations, les taux directeurs sont un instrument peu adapté pour répondre à la formation et au dégonflement de déséquilibres financiers, ce qui soulève la question de savoir si la réglementation «macro-prudentielle» ne serait pas alors plus utile.

Classification JEL : E44, E5, F3, G15

Mots-clefs: taux d'intérêt ; politique monétaire ; logement ; crise des prêts hypothécaires à risque ; marchés financiers; réglementation macro-prudentielle; prix d'actifs; déséquilibres financiers; troubles financiers; innovation financière

To see previous ECO Working Papers, go to www.oecd.org/eco/working papers

\section{Copyright, OECD, 2008}

Application for permission to reproduce or translate all, or part of, this material should be made to: Head of Publication Service, OECD, 2 rue André-Pascal, 75775 Cedex 16, France. 


\section{TABLE OF CONTENTS}

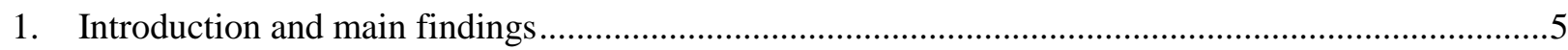

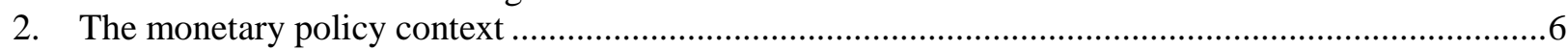

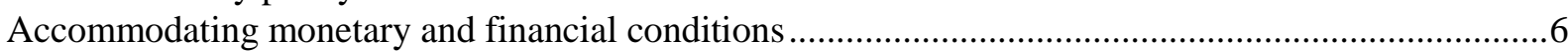

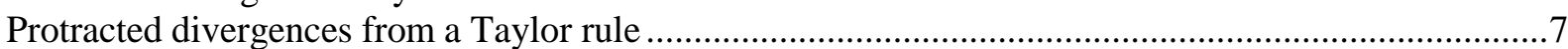

Evidence on links between monetary policy and episodes of financial imbalances .............................15

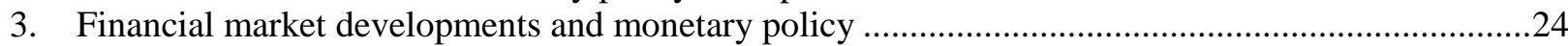

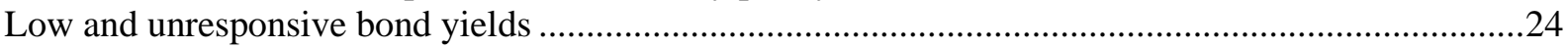

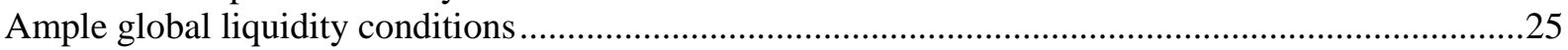

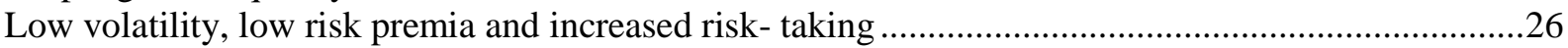

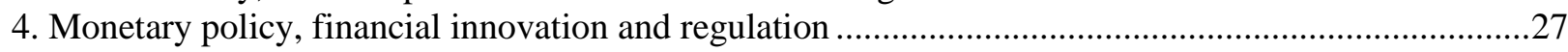

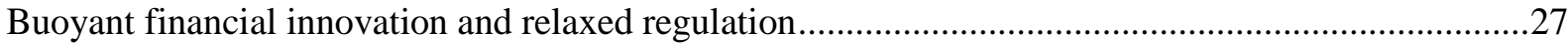

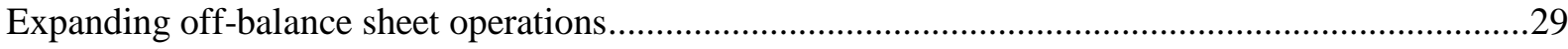

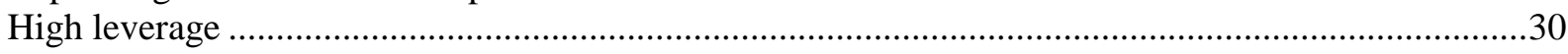

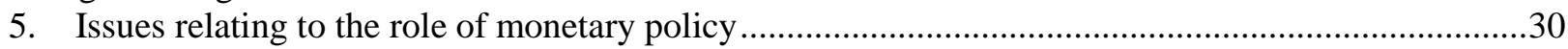

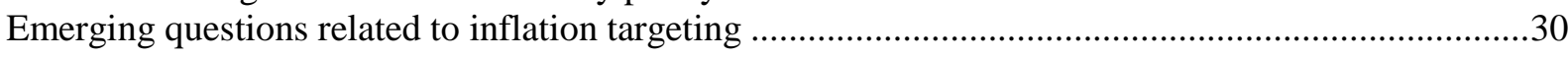

Possible relevance of asset prices for monetary policy ........................................................................

Appropriateness of monetary policy in combating potential bubbles ...................................................31

Potential non-monetary policy options to fight developing financial imbalances .................................32

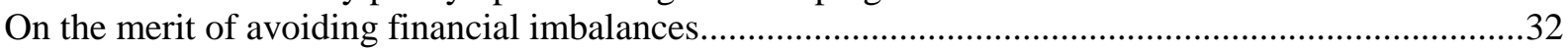

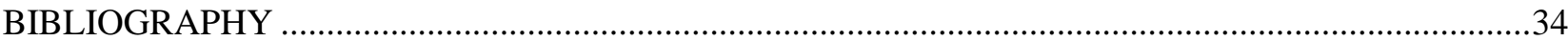

\section{Table}

1. Synthetic information concerning "below-Taylor" episodes

\section{Figures}

1. Nominal and real short-term interest rates

2. $\quad$ Equity indices in emerging markets and OECD house price index

3. Taylor-rule and actual interest rates

4. Robustness of US Taylor rates: fixed vs. time varying neutral rate

5. Robustness of US Taylor rates: variation in assumptions

6. Robustness of Taylor rates to variations in weights for inflation and output stabilisation

7. $\quad$ House prices, Taylor rule and short-term interest rates

8. Deviation from Taylor rule versus various measures of housing activity in the euro area

9. Deviation from Taylor rule versus housing and construction investment in the OECD

10. Deviation from Taylor rule versus various measures of activity for selected countries

11. United States: bond yields and expected average short rate

12. Financial market derived proxies for long-term expected inflation

13. United Sates - outstanding asset backed commercial paper

14. United States: output and inflation volatility

15. Size of global derivatives markets

16. Developments in structured credit markets: Securitised loans and CDO issuance

17. Global hedge fund assets 
ECO/WKP(2008)5 
ECO/WKP(2008)5

\title{
MONETARY POLICY, MARKET EXCESSES AND FINANCIAL TURMOIL
}

\author{
by \\ Rudiger Ahrend, Boris Cournède and Robert Price ${ }^{1,2}$
}

\section{Introduction and main findings}

1. This paper addresses the question of whether and how monetary policy ease may lead to excesses in financial and real asset markets and ultimately result in financial dislocation. A particular focus is on the role that earlier monetary policy may have played in the current financial market turmoil. This question relates both specifically to monetary policy earlier in this decade and more generally to the behaviour of monetary policy in response to shocks. Central banks have been remarkably successful in taming inflation and establishing the conditions for stable growth over the past two decades; financial conditions have also been propitious for growth, for the most part. However, periodic disturbances have occurred to which monetary policy has needed to respond. One possibility is that the recent financial-market turmoil may be, in part, a function of responses to past crises, which have led to an under-pricing of risk, relaxed lending standards, asset (house) price inflation and overleveraging. More fundamentally, the question is whether monetary policy can be too accommodative, even if it does not lead to sustained upward pressure on current prices.

2. The main findings are as follows:

- The available evidence suggests that periods when short-term interest rates have been persistently and significantly below what Taylor rules would prescribe are correlated with increases in asset prices, especially as regards housing. No systematic effects are identified on equity markets, probably reflecting the fact that domestic monetary policy is less important for more globally integrated stock markets.

- Significant asset price increases can also occur when interest rates are in line with Taylor rules, associated with periods of financial deregulation or innovation, which may often give a strong boost to economic activity by themselves and thereby may result in simple Taylor rules being overly conservative.

- Monetary policy was accommodating over the period 2002-2005, and in combination with rapid financial market innovation, would seem in retrospect to have been among the factors behind the run-up in asset prices and financial imbalances -- the (partial) unwinding of which helped trigger the 2007 financial market turmoil. Such accommodation was based, to a substantial degree, on concern about the asymmetric risks associated with deflation and the perceived need to offset financial headwinds.

1. The authors are, respectively, members and head of the Monetary and Fiscal Policy Division of the OECD Economics Department. The views expressed are those of the authors and do not necessarily reflect those of the OECD or its member countries. Corresponding author: Rudiger.Ahrend@ oecd.org

2. The authors are grateful for helpful comments given by Andrew Dean, Jørgen Elmeskov, Peter Hoeller, Peter Jarrett, Randall Jones, Vincent Koen, Andrea de Michelis, Paul O’Brien, Jean-Luc Schneider, David Turner and other members of the Economics Department. They have been heavily reliant on statistical assistance given by Debra Bloch and Catherine Lemoine, and also on secretarial assistance from Paula Simonin, Sandra Raymond and Veronica Humi. The usual disclaimer applies. 
- In certain situations policy rates may be a rather blunt tool for dealing with both the build-up and aftermath of financial imbalances, raising the question whether "macro-prudential" regulation could be useful.

3. The paper is structured in the following way. The next section investigates the degree to which past episodes of monetary ease have been associated with asset-market instability, paying particular interest to the years following the burst of the dot-com bubble. Section 3 explores the policy implications. Sections 4 and 5 examine factors which may have impinged on the capacity of monetary policy to attain both real and financial stability, looking respectively at financial market behaviour and regulation-related issues.

\section{The monetary policy context}

4. The current turmoil is complex and unique in its nature, and a number of factors have certainly played a significant role, such as financial innovation, global capital flows, lax lending practices, and an overly high discounting of risk on the part of investors. To set the turmoil in its monetary policy context, this section first assesses monetary conditions of recent years, examining how far interest rates may have diverged from Taylor rule levels. It then turns to comparable historical situations, examining the association of episodes of monetary policy ease with the build-up of financial imbalances.

\section{Accommodating monetary and financial conditions}

5. Both long- and short-term interest rates have come down significantly over the past two decades, and compared with the averages of previous decades were low, both in real and nominal terms throughout the first years of the $21^{\text {st }}$ century. Short rates were particularly low in 2002-04, both in real and nominal terms, not only in the United States but also a number of other economies (Figure 1). At the same time, inflation remained low and stable, but a number of asset prices, including emerging market equity, housing, and art experienced fairly strong growth during this period (Figure 2). As the counterpart of falling yields, bond prices also underwent exceptional increases.

Figure 1. Nominal and real short-term interest rates
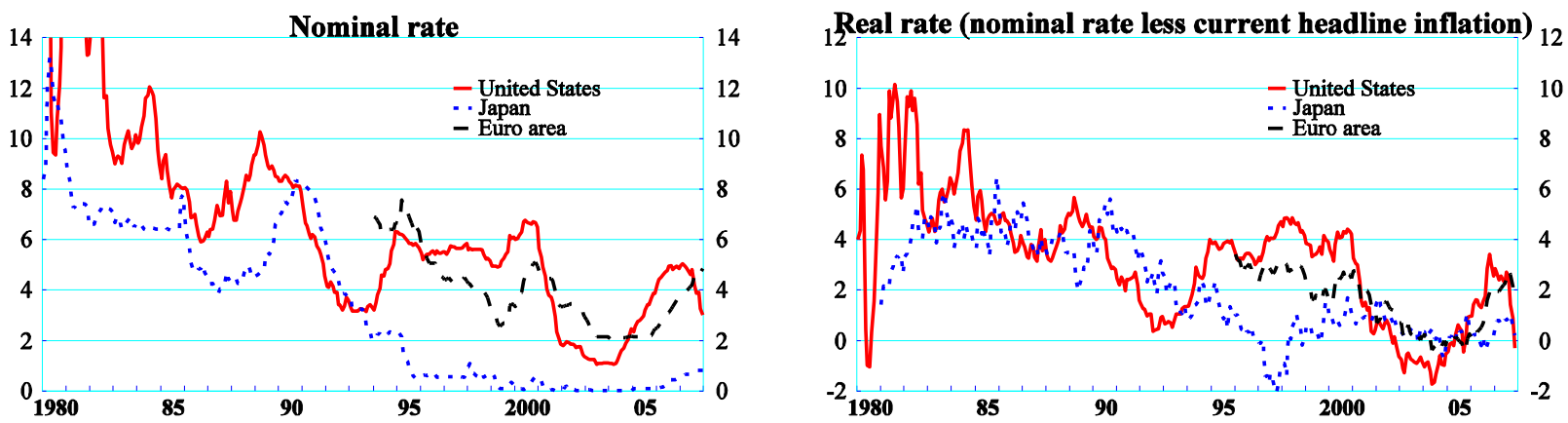

Note: Real interest rates are calculated as the nominal interest rate ( 3 month treasury bills for the US) less the annual headline inflation rate. (Headline PCE deflator for the United States; headline HICP for the euro area and and headline CPI Japan).

Source: OECD. 
6. While the monetary policies pursued by the majority of OECD economies have, over the past decade, been a remarkable success in terms of stabilising inflation outcomes and expectations, the question arises as to whether easy monetary policies, in combination with financial innovation and other factors, may have fuelled asset price behaviour which led to the development of financial imbalances that are behind the current financial turmoil. Inflated sub-prime lending, in addition to being driven by undisciplined innovation and inadequate regulation, was underwritten by exaggerated expectations of rising house prices (the subsequent collapse of which is increasing the losses incurred and resolving the problems is more difficult) and an apparent confidence in continuing monetary accommodation. Such attitudes may have reflected that, on several occasions, interest rates have been cut or maintained at low levels in the wake of episodes of financial market turmoil, as was the case following both the Russia and LTCM crisis and the bursting of the dot-com bubble. While central banks have stressed that those changes were not a reaction to financial distress per se, but justified by the resulting changes in the inflation and growth outlook, financial markets may have widely come to believe that, if needed, they would be bailed out by central bank action. The fact that in situations of systemic danger to the financial sector, central bank actions will naturally be motivated by crisis management has been argued to create a moral hazard which stimulates future financial imbalances, basically sowing the seeds of bigger trouble to come. ${ }^{3}$

Figure 2. Equity indices in emerging markets and OECD house price index
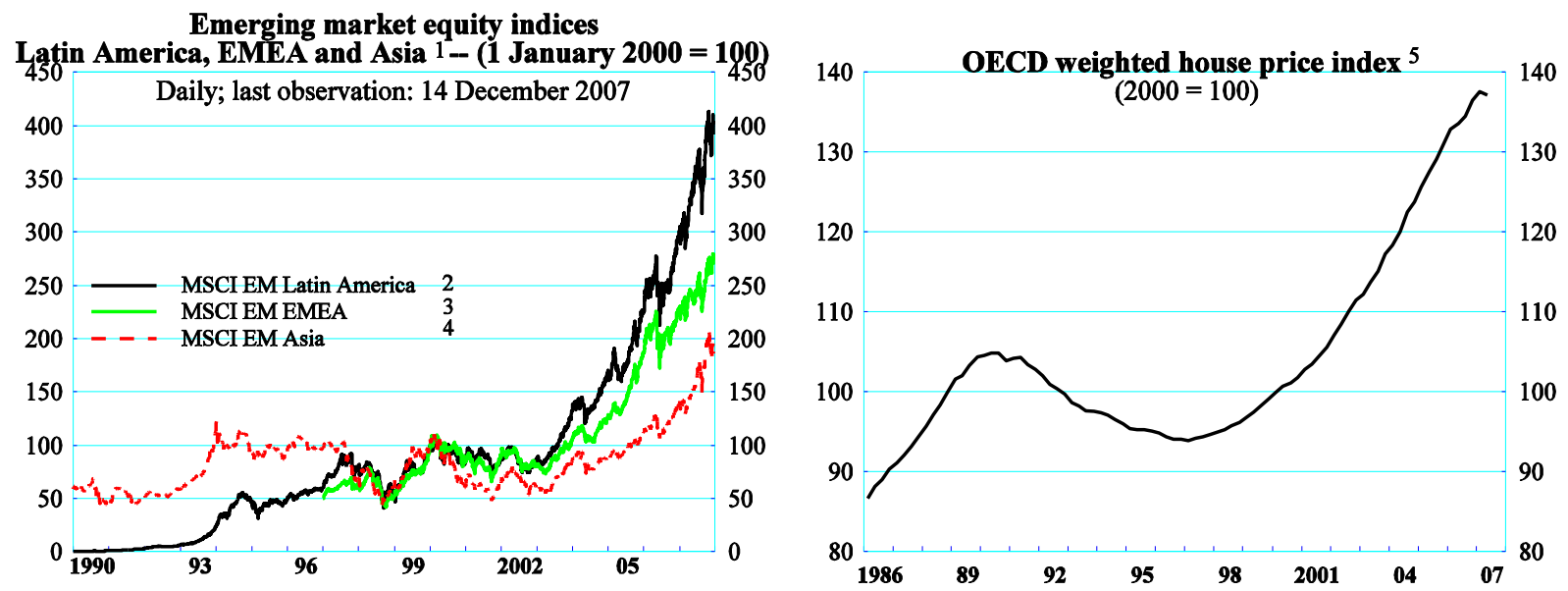

1. EMEA includes Europe, Middle-East and Africa

2. MSCI Emerging Markets Latin America is a free float-adjusted market capitalisation index that is designed to measure equity market performance in Latin America. As of June 2006 it includes Argentina, Brazil, Chile, Colombia, Mexico and Peru.

3. MSCI Emerging Markets EMEA is a free float-adjusted market capitalisation index that is designed to measure equity market performance in the emerging market countries of Europe, the Middle East and Africa. As of June 2006 it includes Czech Republic, Hungary, Poland, Russia, Turkey, Israel, Jordan, Egypt, Morocco and South Africa.

4. MSCI Emerging Markets Asia is a free float-adjusted market capitalisation index that is designed to measure equity market performance in the emerging market countries of Asia. As of June 2006 it includes : China, India, Indonesia, Korea, Malaysia, Pakistan, Philippines, Taiwan, and Thailand.

5 Real house price index of 18 OECD countries (Australia, Canada, Denmark, Finland, France, Germany, Ireland, Italy, Japan, Korea, Netherlands, New Zealand, Norway, Spain, Sweden, Switzerland, United Kingdom and United States), aggregated using a weighting scheme based on 2000 GDP and PPPs as weights.

Sources: Morgan Stanley, Thompson Financial and OECD calculations.

\section{Protracted divergences from a Taylor rule}

7. As a first step towards examining whether periods of monetary ease tend systematically to be associated with instability in asset prices, this sub-section compares actual interest rates with normative benchmarks based on Taylor rules. Indeed, in the early years of the $21^{\text {st }}$ century, interest rates were, for

3. See, for example, King (2007). For a critical response to King see, for example, Summers (2007). 
many economies, below the level a standard Taylor rule would have suggested. This finding is fairly robust to different assumptions and methodologies that can be used to estimate a Taylor rule.

8. Such a rule stipulates the level of policy rates to be a function of the output gap, divergences of actual rates of inflation from a target, and the neutral level of interest rates. ${ }^{4}$ In the following, a standard specification is used:

$$
\mathrm{r}_{\mathrm{T}}=\pi+\mathrm{r}^{*}+\lambda_{1}\left(\pi-\pi^{*}\right)+\lambda_{2}(\mathrm{GAP})
$$

with $\mathrm{r}_{\mathrm{T}}$ being the Taylor interest rate, $\pi$ the rate of inflation as measured by core CPI, ${ }^{5} \pi^{*}$ the desired rate of inflation, $\mathrm{r}^{*}$ the assumed real "neutral" rate, and GAP the output gap. $\lambda_{1}$ and $\lambda_{2}$ are the weights given to, respectively, inflation and output stabilisation, with the constraint that they should add up to one. For simplicity, and as widely adopted in the literature, equal weights on output and inflation stabilisation are assumed here, i.e. $\lambda_{1}=\lambda_{2}=0.5$. As monetary conditions are also influenced by exchange rate movements, the inclusion of some form of exchange rate variable into a Taylor-style equation could be envisaged. Studies on the subject indicate, however, that the inclusion of an exchange rate variable in Taylor-type rules is not helpful for inflation and output stabilisation ${ }^{6}$ and this work therefore abstracts from exchange rates. Intuitively, as exchange rate misalignments can be very protracted, it would not seem a desirable feature to rely on a general rule that would bias monetary policy significantly up or downwards for years merely because of exchange rate levels. ${ }^{7}$

9. There are some potential difficulties in calculating Taylor rates which might affect their operational significance. For example, the output gap and the neutral rate are not observable, and estimates for these variables can be challenged (Cotis et al., 2004). Problems are generally exacerbated when going back in time, especially where inflation was high and volatile, so that this study largely abstracts from the pre-1985 period. For simplicity, it is assumed that in the late 1980s and early 1990s, central banks pursued the same inflation objectives as they do today, even though inflation rates in many countries were still significantly above levels witnessed during the past decade and some central banks were still mainly focused on monetary aggregates. It also seems likely, and is supported by evidence for some countries, that real neutral rates have been time-variant, and may have come down somewhat over recent decades. However, with the exception of the United States, for which such a time path is readily available, estimates of current neutral rates are used as proxies for historical values. ${ }^{8}$ This could bias Taylor-rate estimates downward in earlier periods. On the other hand, for the earlier years the inflation targets assumed in the current Taylor-rule calculations may be overly ambitious, possibly biasing Taylor-rate estimates upward. All in all, the approach chosen to calculate Taylor rates may result in some potential "below Taylor" episodes in earlier years not being captured, which may explain why prior to 2000 only relatively few of such episodes are found. ${ }^{9}$

4. This rule was first proposed for the United States in Taylor (1993). For a critical discussion of the Taylor rule see, for example, Kohn (2007).

5. For the United States, core PCE is used.

6. See, for example, Taylor (2002).

7. A stronger case for systematically considering exchange rates can be made when not looking at monetary policy stance in levels (as is done here), but in changes.

8. Neutral rates are derived from the OECD medium-term reference scenario. Time variant neutral rates for the United States are taken from $\mathrm{Wu}(2005)$.

9. This may also be connected with the fairly general need for disinflation during the 1980s, as well as the relatively benign global environment after 2000, which allowed for low interest rates resulting in relatively little inflationary pressure. 
10. Using a standard Taylor rule as stipulated above, a fairly large number of episodes can be identified where policy rates have been persistently and significantly below prescribed levels (Figure 3). ${ }^{10}$ As noted, the largest part of those episodes are recent, though there are also some historical precedents (see below).

10. Using quarterly data, an episode is defined as a time period with a cumulated deviation from a Taylor rule of at least 12 percentage points. This would, for example, correspond to a deviation by one percentage point during three years, or a deviation by 1.5 percentage points during two years. For most episodes, deviations are well above this threshold. For the largest cases, this threshold is surpassed by a factor of above ten (Ireland 1999-2007), or above six (Portugal 1998-2005, Spain 1998-2007 and Greece 2000-07). For the US 2001-06 episode, this threshold is still surpassed by a factor of almost four. 
Figure 3. Taylor rule and actual interest rates
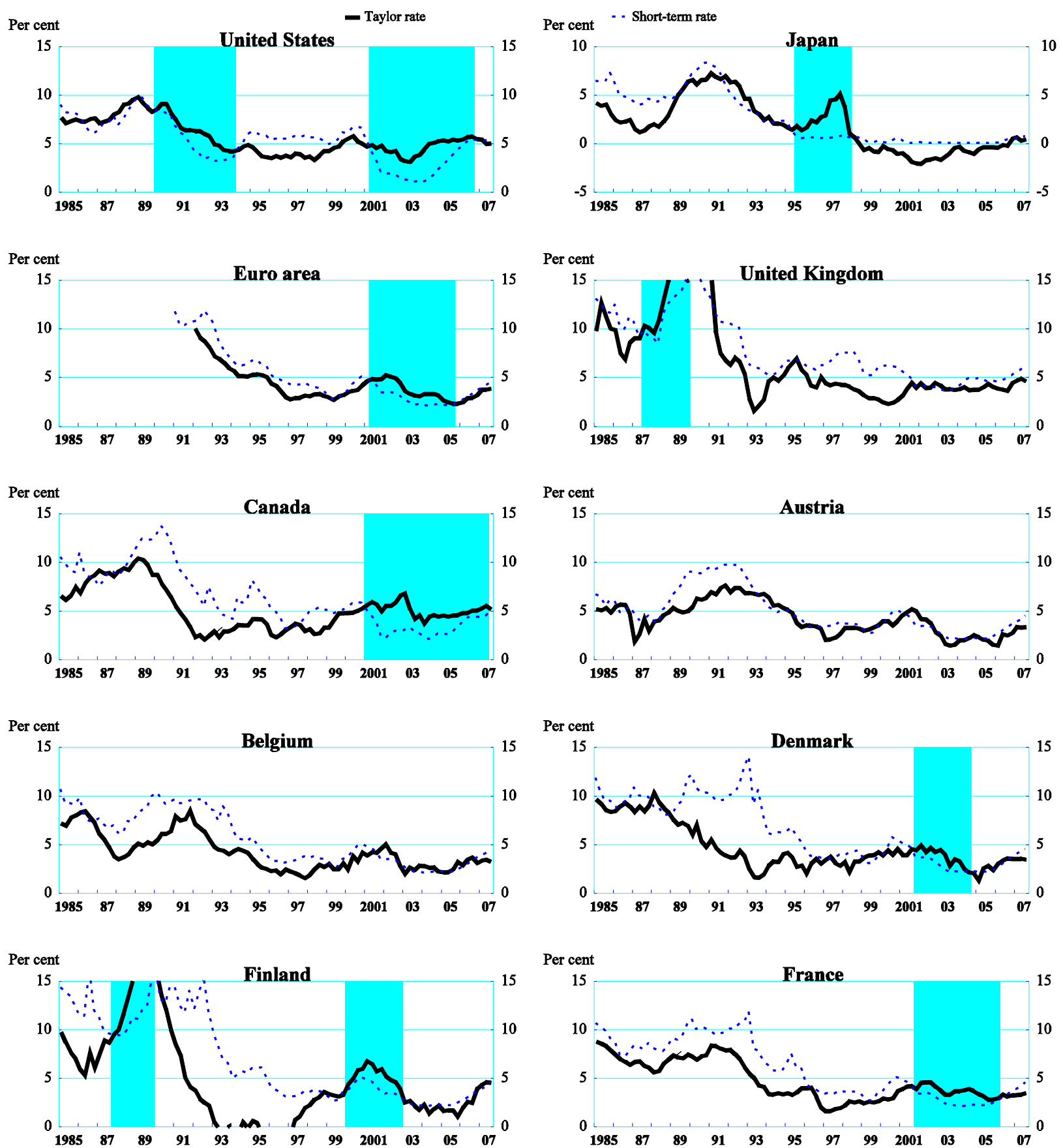

Note: The Taylor rule rate is a function of an equilibrium real interest rate (short term), the (implicit) inflation target, the average output gap and the gap between actual inflation and the implicit inflation target.Equal weight is given to the inflation gap and the output gap.

For United States, the assumed price stability target is for inflation of $1.9 \%$ and the assumed equilibrium real interest rate is $2.85 \%$.

For Japan, the assumed price stability target is for inflation of $1.0 \%$ and the assumed equilibrium real interest rate is $1.2 \%$.

For the euro area countries, the assumed price stability target is for inflation of $1.9 \%$ and the assumed equilibrium real interest rate is $2.1 \%$.

For United Kingdom, the assumed price stability target is for inflation of $2.0 \%$ and the assumed equilibrium real interest rate is $3.0 \%$.

For Canada, the assumed price stability target is for inflation of $2.0 \%$ and the assumed equilibrium real interest rate is $2.75 \%$.

Source: OECD. 
Figure 3. Taylor rule and actual interest rates (cont.)
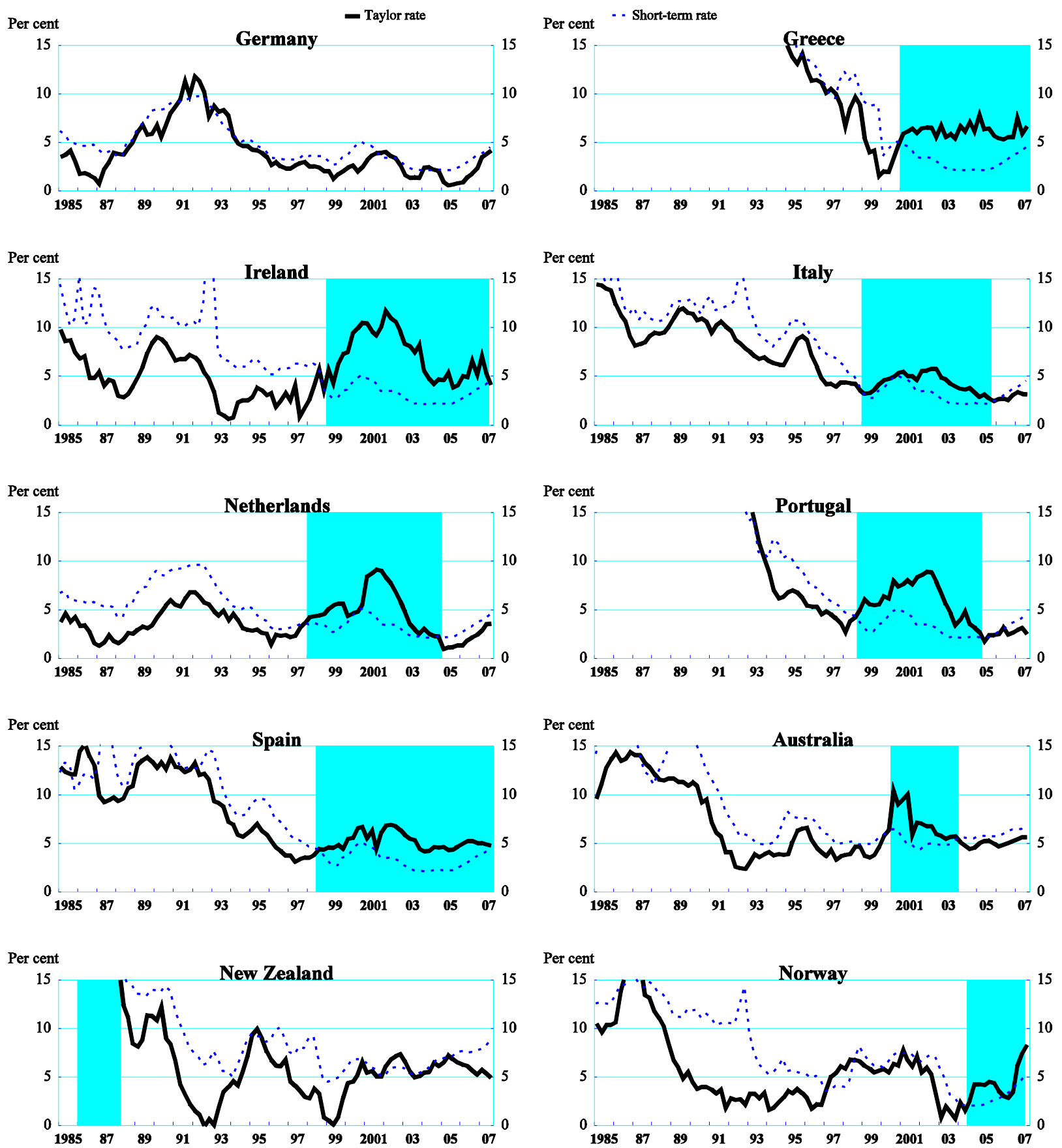

Note: The Taylor rule rate is a function of an equilibrium real interest rate (short term), the (implicit) inflation target, the average output gap and the gap between actual inflation and the implicit inflation target.Equal weight is given to the inflation gap and the output gap.

The assumed price stability target is for inflation of $1.9 \%$ and the assumed equilibrium real interest rate is 2.1 for the euro area countries.

For Australia, the assumed price stability target is for inflation of $2.5 \%$ and the assumed equilibrium real interest rate is 2.85 .

For New Zealand, the assumed price stability target is for inflation of $2 \%$ and the assumed equilibrium real interest rate is 3 .

For Norway, the assumed price stability target is for inflation of $2 \%$ and the assumed equilibrium real interest rate is 2.4.

Source: OECD. 
Figure 3. Taylor rule and actual interest rates (cont.)
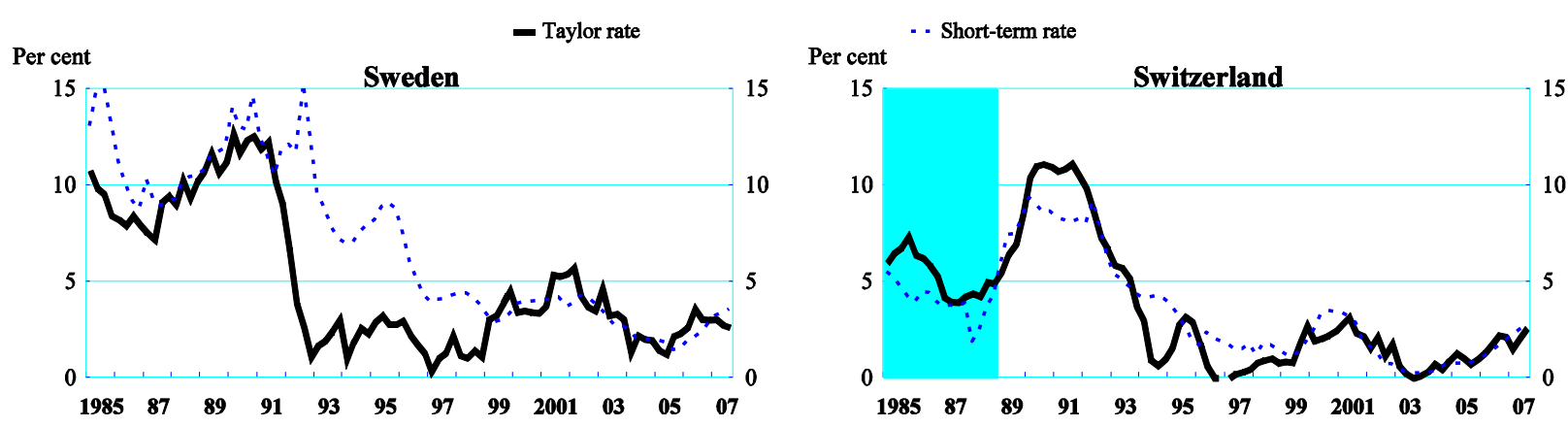

Note: The Taylor rule rate is a function of an equilibrium real interest rate (short term), the (implicit) inflation target, the average output gap and the gap betwe actual inflation and the implicit inflation target.Equal weight is given to the inflation gap and the output gap

For Sweden, the assumed price stability target is for inflation of $2 \%$ and the assumed equilibrium real interest rate is 2.1

For Switzerland, the assumed price stability target is for inflation of $1.0 \%$ and the assumed equilibrium real interest rate is 1.6

Source: OECD.

11. Given the potential difficulties in determining Taylor rates, the robustness of the identified episodes to different assumptions and methodologies has been tested. The general result is that, while the exact timing of identified episodes may differ somewhat, their identification is fairly robust. For example, using a fixed or a time-varying neutral rate does not seem of major importance for the United States, for which time-varying estimates are available (see Figure 4).

Figure 4. Robustness of US Taylor rates : fixed vs. time varying neutral rate
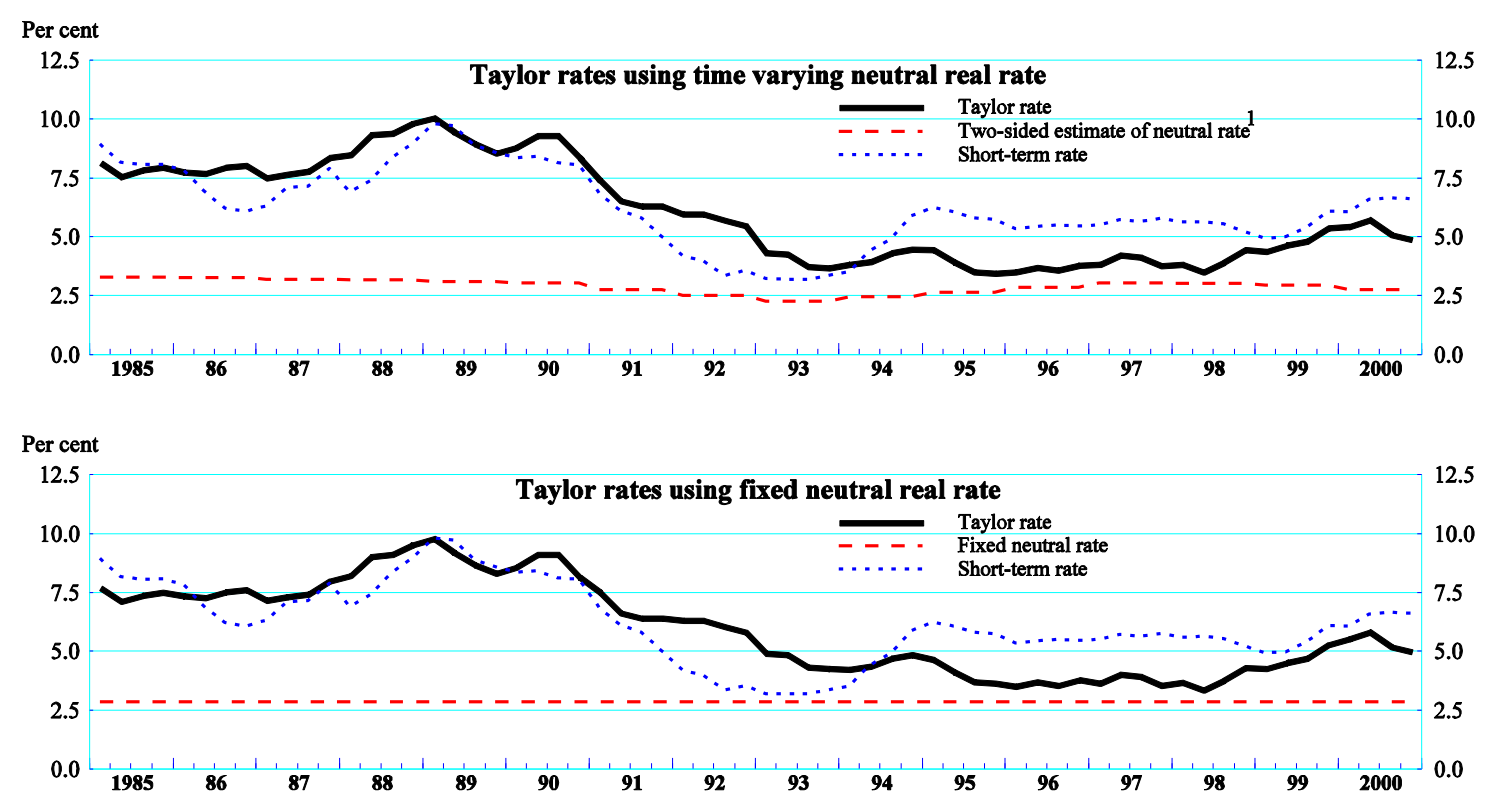

1. Time varying neutral rates are taken from $\mathrm{Wu}(2005)$ Source: OECD.

12. Also, identified episodes seem generally unaffected by the use of different (reasonable) assumptions about the level of the neutral rate, or inflation targets. Figure 5, Panel A shows, for example, that negative neutral rates would need to be assumed in order to argue that US rates in 2002-05 were not below Taylor rates. Similarly, for any inflation target between 0 and 4\%, actual US rates in 2002-05 were significantly below Taylor rates (Figure 5, Panel B). Identified episodes are, finally, also robust to different weights on inflation and output stabilisation. Even under fairly extreme scenarios with weights of 0.7 and 
0.3 (using, in turns, a stronger weight on inflation or output stabilisation), identified episodes remain unchanged (see Figure 6).

Figure 5. Robustness of US Taylor rates : variation in assumptions

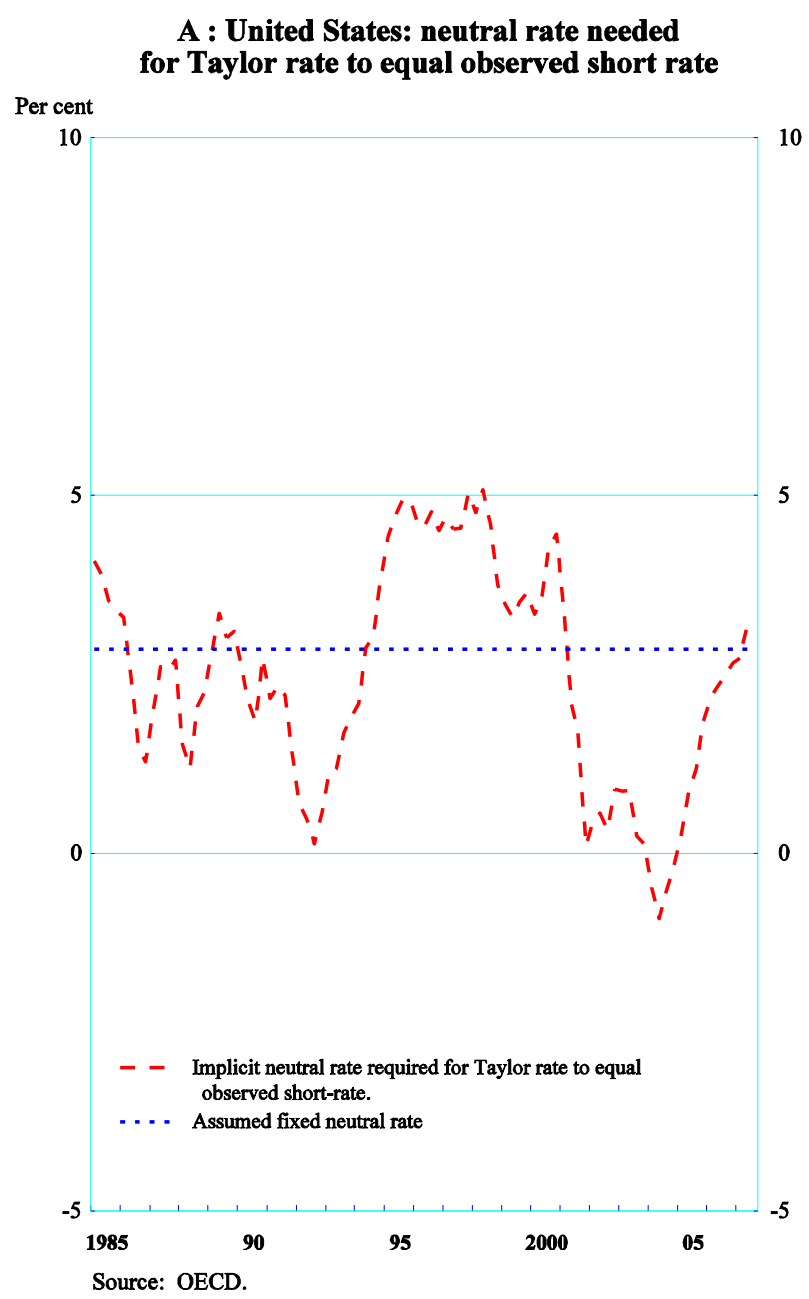

B : United States: Observed short-term rate vs Taylor rate under different assumptions about target inflation rate Per cent

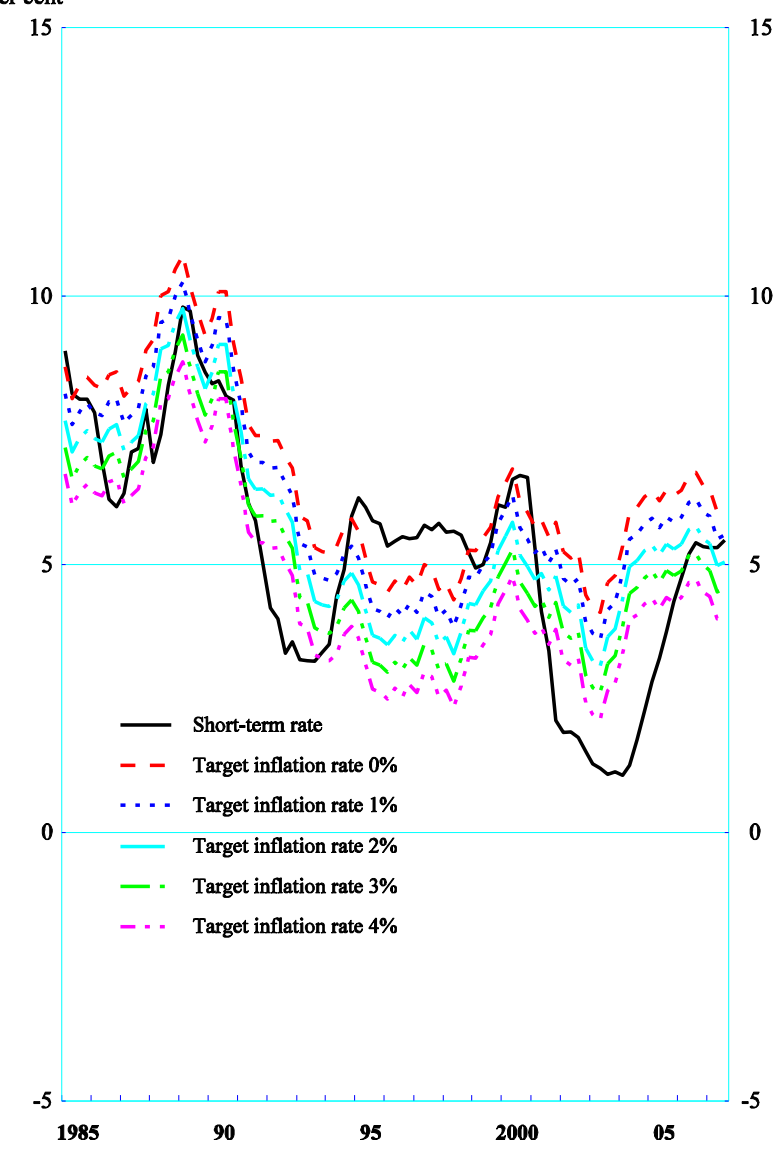


Figure 6. Robustness of Taylor rates to variations in weights for inflation and output stabilisation
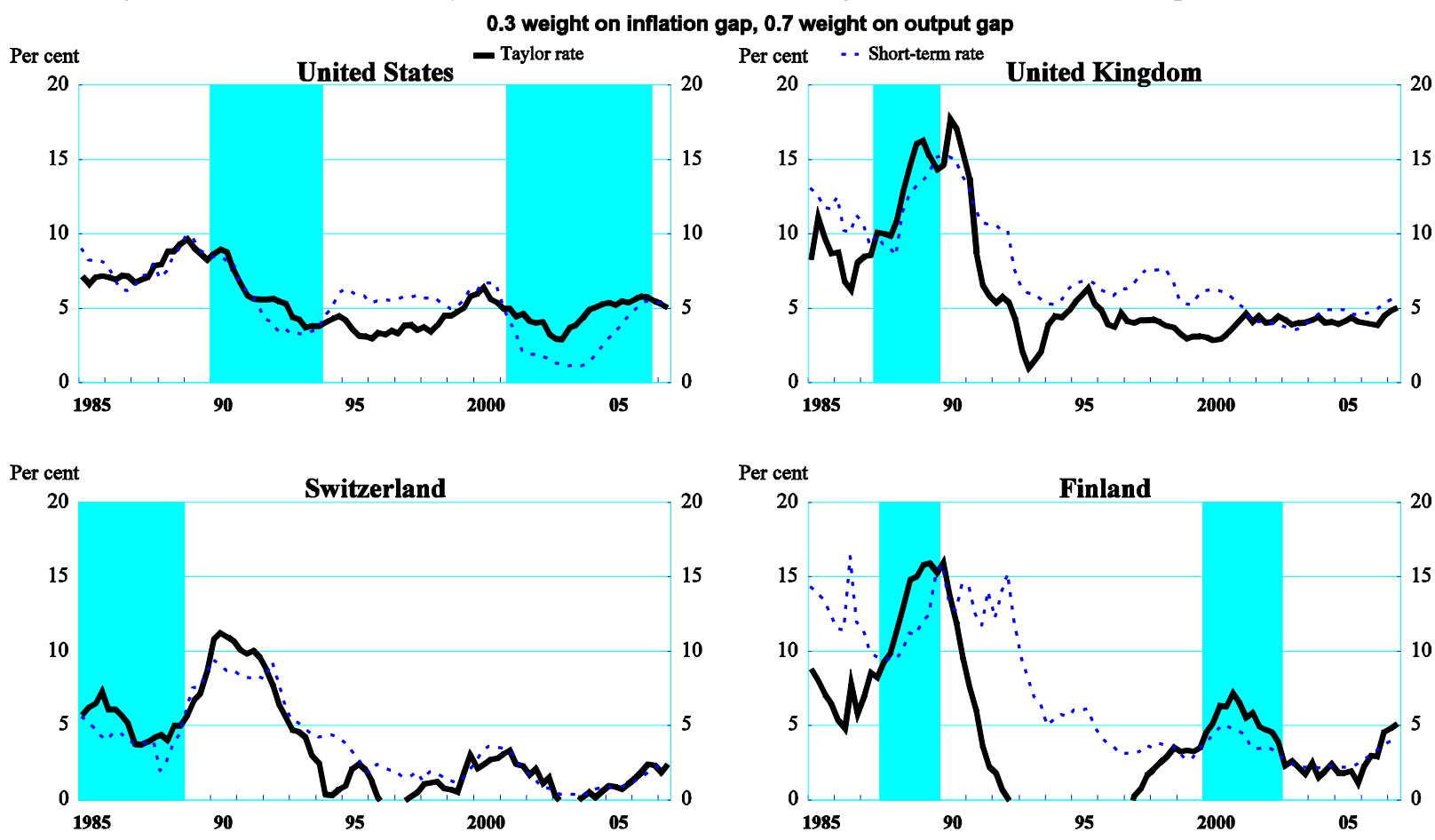

0.7 weight on inflation gap, 0.3 weight on output gap

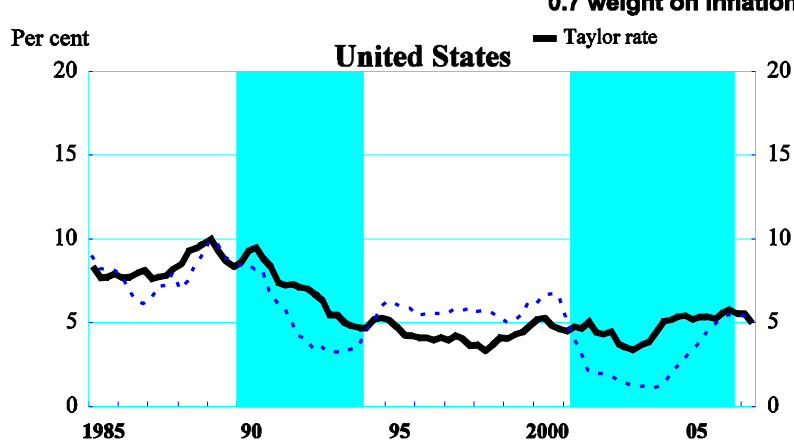

Per cent - - Short-term rate
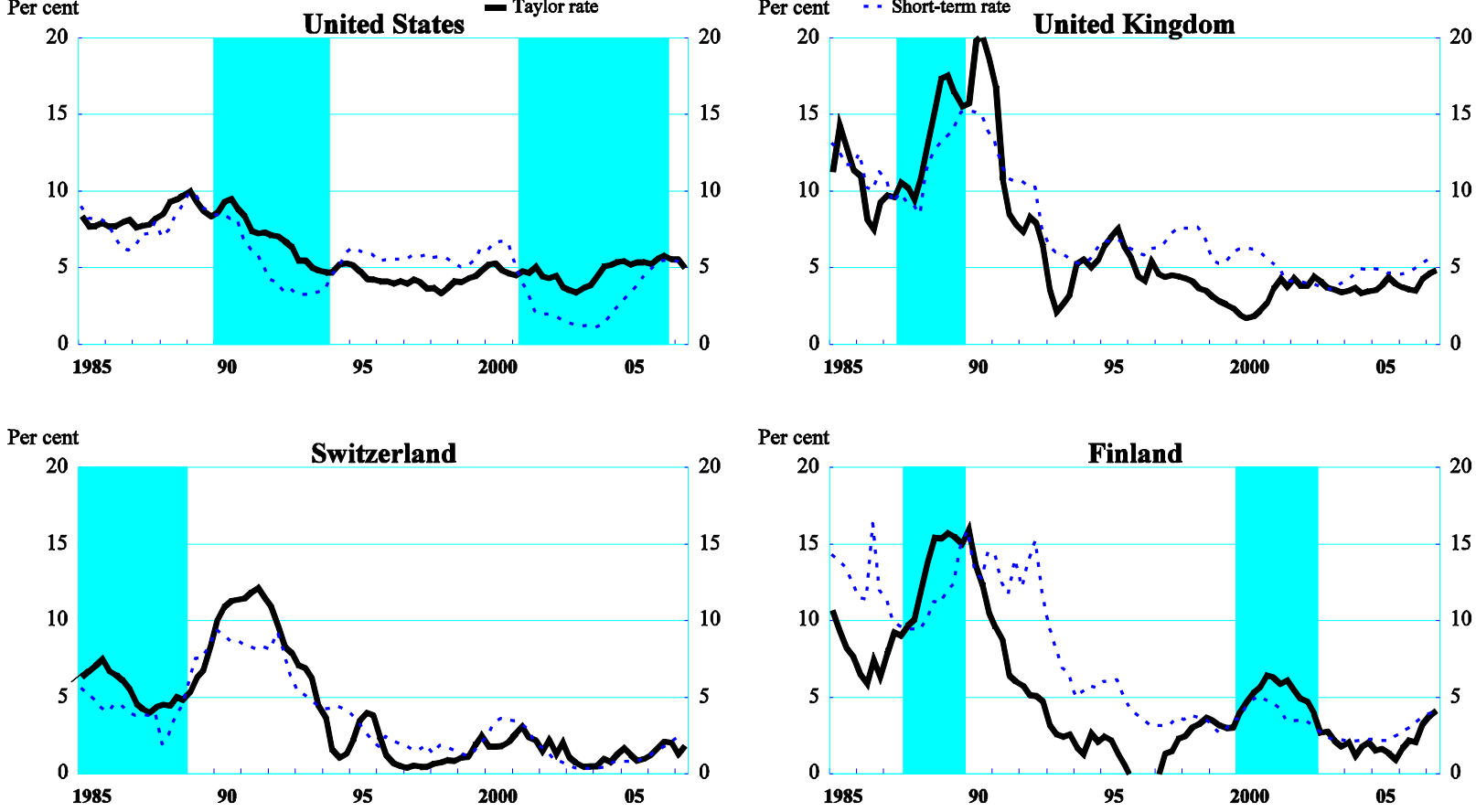

Note: The Taylor rule rate is a function of an equilibrium real interest rate (short term), the (implicit) inflation target, the average output gap and the gap between actual inflation and the implicit inflation target. Similar graphs are available for most other OECD countries upon request.

For United States, the assumed price stability target is for inflation of $1.9 \%$ and the assumed equilibrium real interest rate is $2.85 \%$.

For United Kingdom,the assumed price stability target is for inflation of $2.0 \%$ and the assumed equilibrium real interest rate is $3.0 \%$.

For Switzerland, the assumed price stability target is for inflation of $1.0 \%$ and the assumed equilibrium real interest rate is $1.6 \%$.

For Finland, the assumed price stability target is for inflation of $1.9 \%$ and the assumed equilibrium real interest rate is $2.1 \%$.

Source: OECD. 
13. A number of factors provided justification for keeping policy rates below those which a Taylor rule would have implied, warning against the interpretation of divergences from Taylor rule as necessarily implying a deviation from an optimal policy setting. Apart from the fallout from a number of high-profile corporate scandals in the early 2000s, which created financial headwinds not captured by simple Taylor rules, the most important was the fear that other large economies might follow Japan into deflation. ${ }^{11}$ Given the perceived asymmetry in the costs involved -- falling into deflation generally being considered as more difficult and costly to correct than some overshooting of inflation targets -- a risk management approach was thought to call for erring on the side of ease. This approach was easier to adopt in an environment of globalisation-induced disinflation, which was initially seen as helping central banks to keep domestic inflation at levels consistent with their respective understanding of price stability while running the economy at higher levels of activity. ${ }^{12}$ At the same time, bond yields remained historically low, reflecting mainly a combination of high saving and strong reserve accumulation by central banks in surplus-generating emerging markets, but also high saving relative to investment in the corporate sector in the OECD; this bond market stability appeared to indicate well-anchored inflation expectations in the face of easy monetary policy. Finally, in a monetary union such as the euro area, the central bank obviously had to focus on the currency area in its entirety when setting interest rates, even if this had asymmetric effects on asset prices which, potentially, could lead to financial imbalances in some member countries.

14. Several factors were affecting the transmission of monetary policy which might have suggested that the potential problems of undershooting Taylor rates were increasing. ${ }^{13}$ A corollary of the bond market "conundrum" was that long-term rates failed to rise when policy rates finally increased, meaning that financial conditions remained extremely accommodative, while risk premia and volatility were artificially low. Also, low interest rates were occurring in an environment of strong financial innovation and off-balance sheet expansion, which meant that monetary policy influence on overall liquidity creation was diminishing. On the other hand, the wealth effects of monetary policy were being amplified by financial deepening, so that the potential problems of undershooting Taylor rates were increasing from the asset price side. Evidence on the links between episodes of monetary policy ease and asset prices is examined in the next section, followed by a discussion of the role of low bond yields, rapid liquidity creation and low risk premia in making asset price inflation destabilising.

\section{Evidence on links between monetary policy and episodes of financial imbalances}

15. Whether interest rates lower than the level indicated by a standard Taylor rule in 2002-05 contributed to the rapid run-up in house prices in the United States is a matter of controversy. ${ }^{14}$ During the same period, incomplete business cycle convergence within the euro area resulted in a situation where, for some member countries including Ireland and Spain in particular, monetary policy rates set to be consistent

11. See, for example, Kohn (2004).

12. See Pain et al. (2006). The effects of globalisation were temporarily to allow inflation targets to be achieved at lower rates of interest and higher rates of activity (as low imported inflation compensated for higher domestic inflation). Meeting inflation targets at higher levels of activity may also have been driven by technological progress and the IT revolution. A focus on the advantages of globalisation in easing inflation constraints due to the flattening of the domestic Phillips curve was gradually to give way to concern about the persistent effects of the global expansion on energy, food and other commodity prices; at the same time, the distribution of risks facing monetary policy action began to take account of the fact that flatter Phillips Curves also meant that reducing inflation if it got out of hand would involve potentially heavier costs, as the leverage of monetary policy on inflation was reduced.

13. For a discussion of the changes in the transmission of monetary policy as a result of financial market trends, see Cournede et al. (2008).

14. See, for example, Taylor (2007) and Negro and Otrok (2007) for opposing views. 
with conditions in the euro area as a whole were persistently and significantly below what a "countryfocused" Taylor rule would have suggested. Most of these countries experienced particularly strong house price increases (Figure 7). ${ }^{15}$

Figure 7. House prices, Taylor rule and short-term interest rates
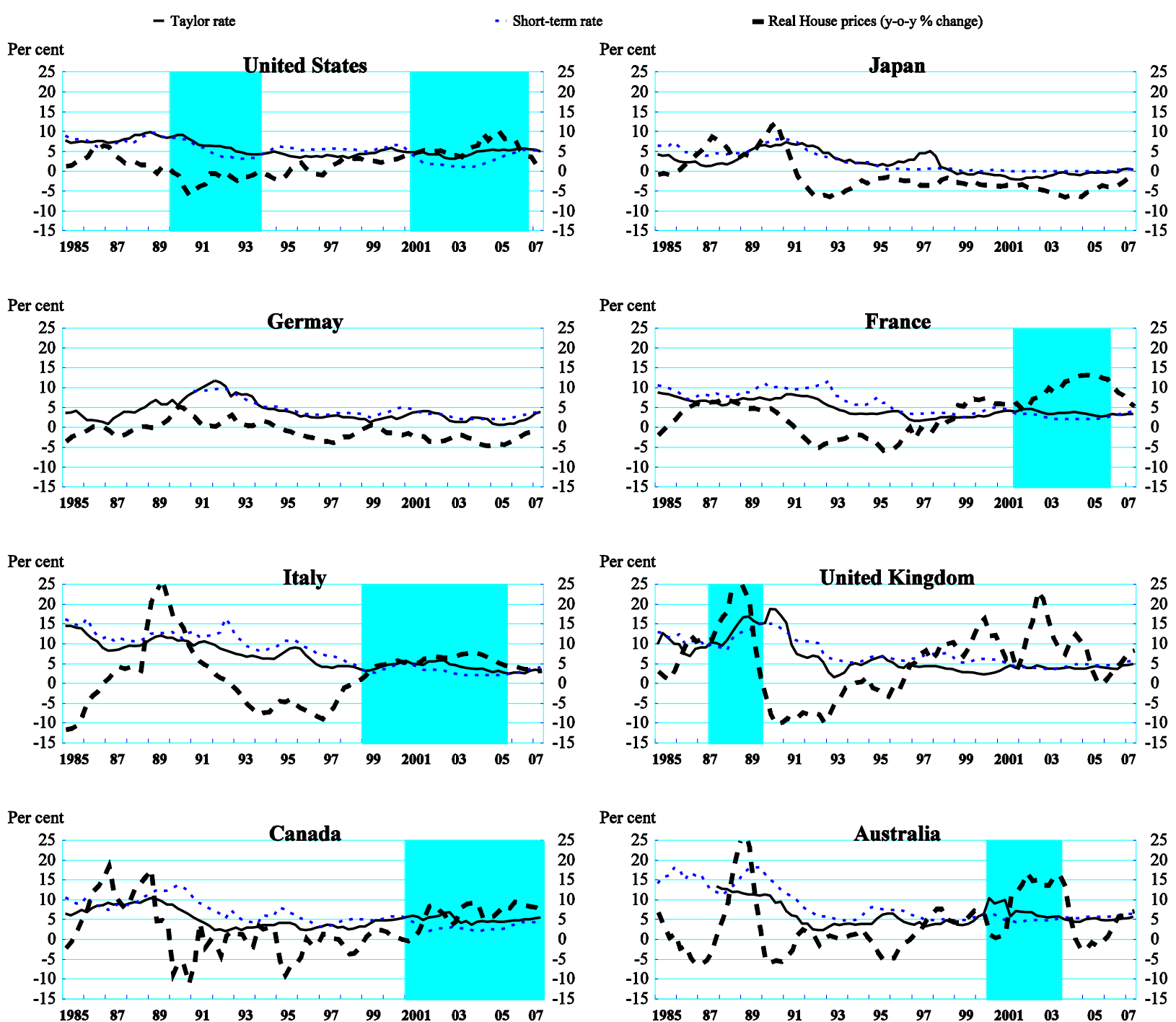

15. On the nexus between house prices and financial imbalances see, for example, Girouard et al. (2006) or van den Noord (2006). On the rareness of soft landings following residential investment booms, see Rae and van den Noord (2006). 
Figure 7. House prices, Taylor rule and short-term interest rates (cont.)
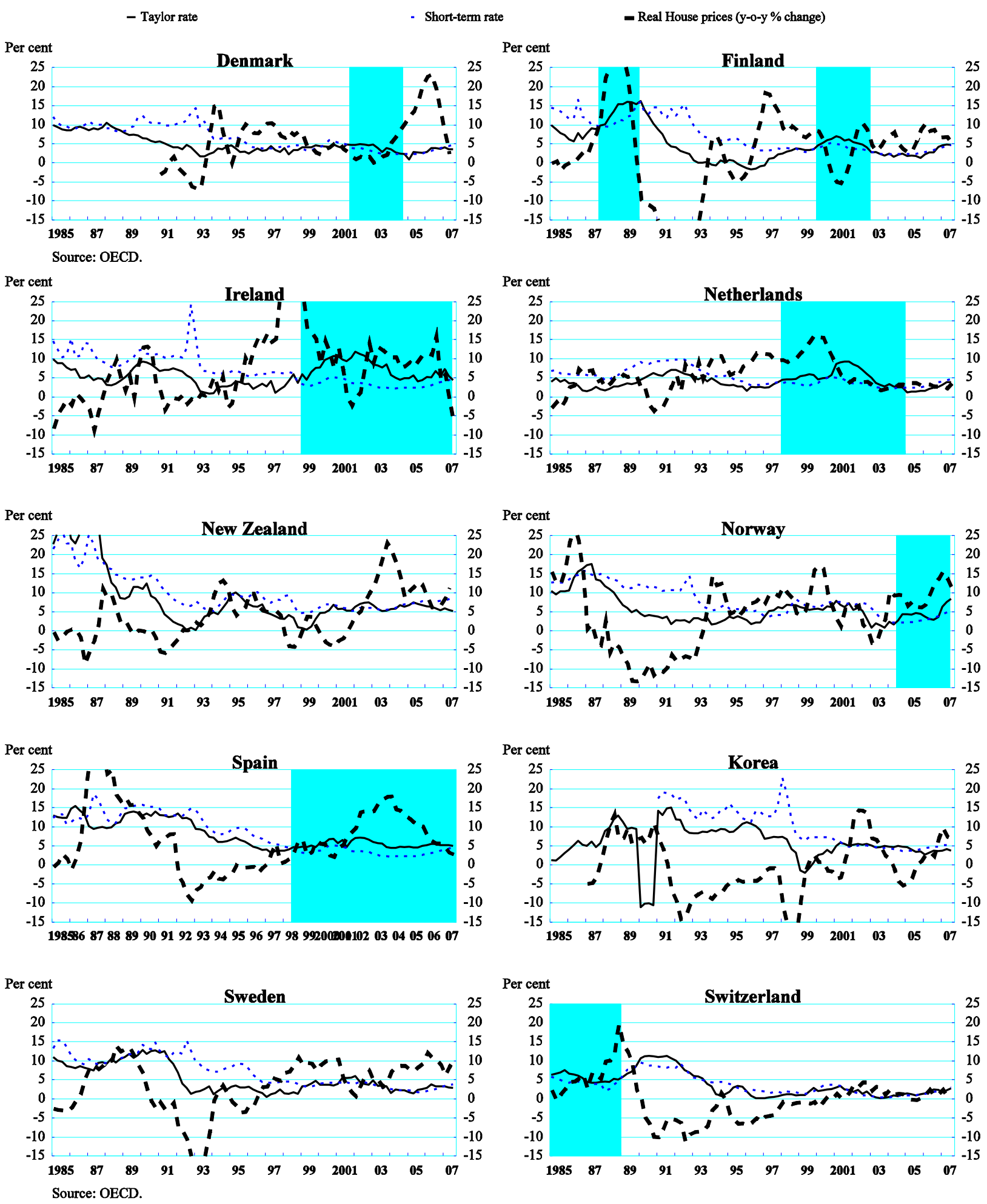
16. Over the 2001-06 period, the correlation between various indicators of housing market buoyancy and the distance of respective euro area countries from a Taylor-rule benchmark rate is indeed striking (Figure 8). Mortgage lending, housing investment, construction investment, and house prices all show a fairly strong correlation with deviations from a Taylor rule. The correlation with house prices is actually the weakest, which is not surprising as differences in zoning restrictions (which should be uncorrelated with monetary policy stance) would also be expected to have a significant influence on price developments. ${ }^{16}$ While somewhat weaker, the correlation between various indicators of housing market buoyancy and the distance of respective countries from a Taylor-rule benchmark rate also seems to persist when looking at a broader country sample (Figure 9).

Figure 8. Deviation from Taylor rule versus various measures of housing activity in the euro area
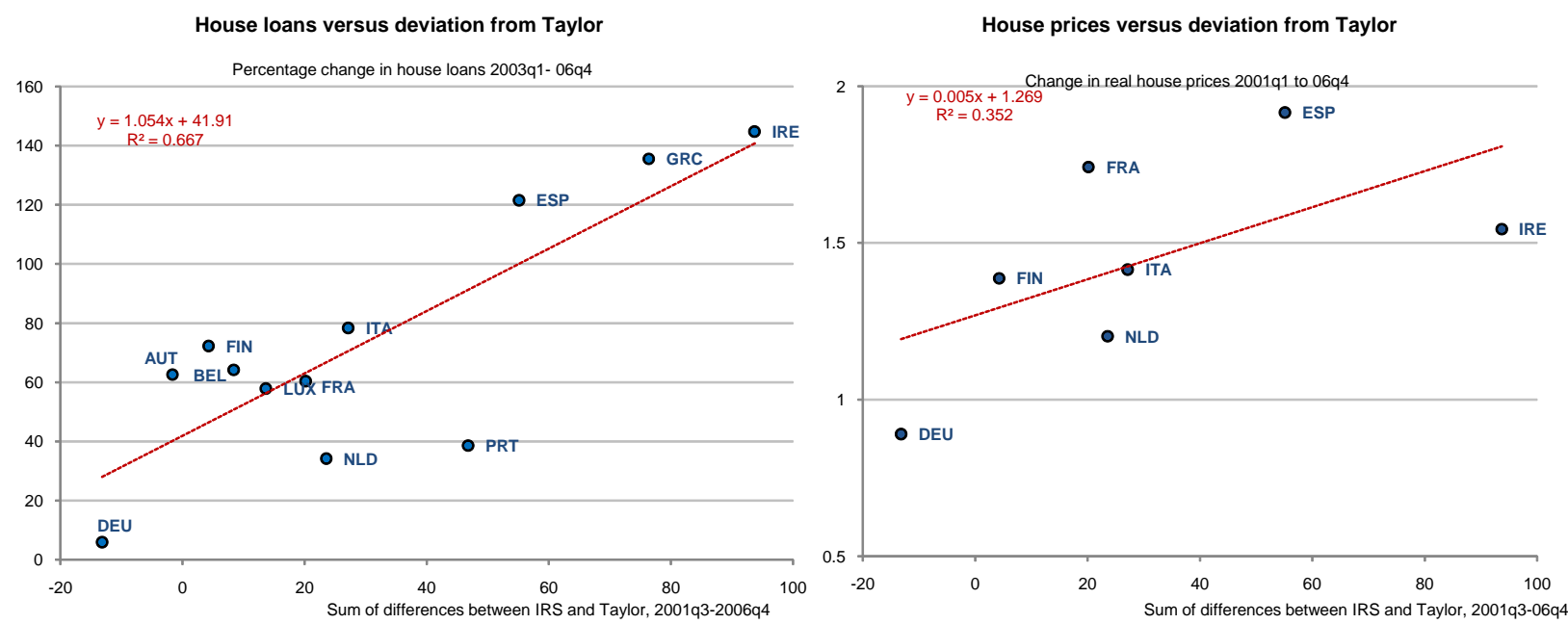

Housing investment versus differences between IRS and Taylor

Construction investment versus differences between IRS and Taylor
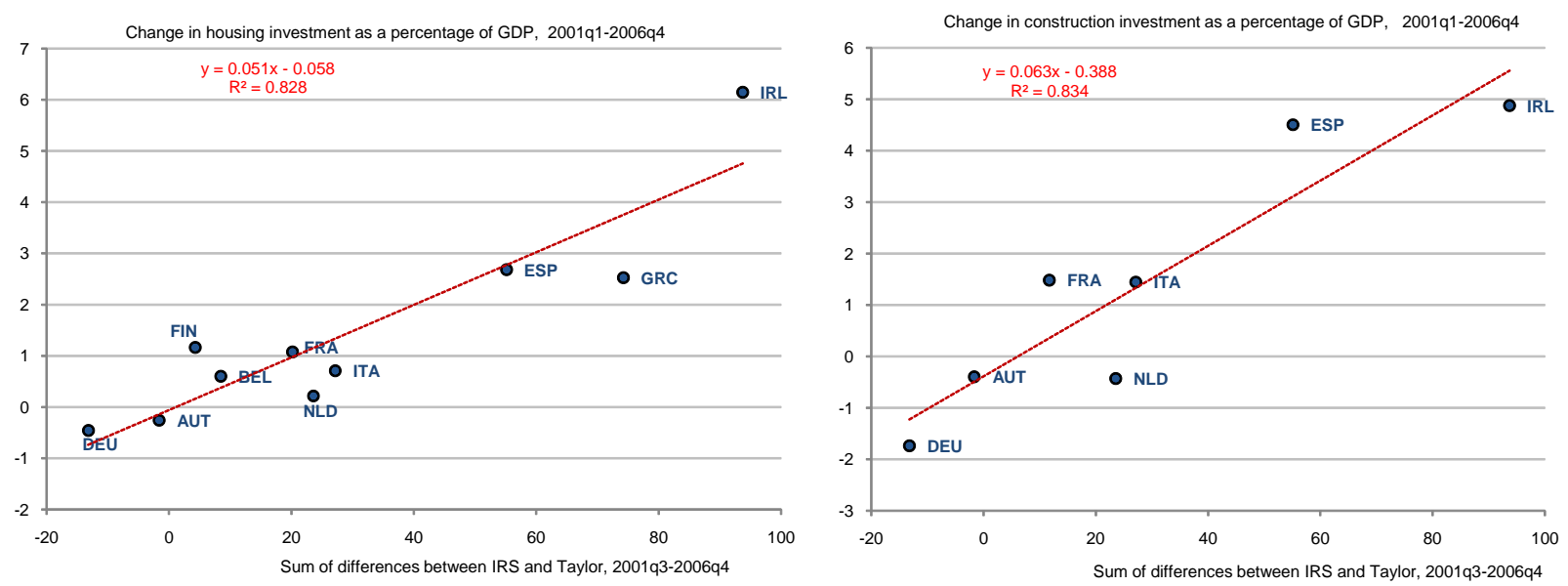

Source: OECD.

16. See, for example, Hoeller and Rae (2007). 
Figure 9. Deviation from Taylor rule versus housing and construction investment in the OECD

Housing investment versus deviation from Taylor

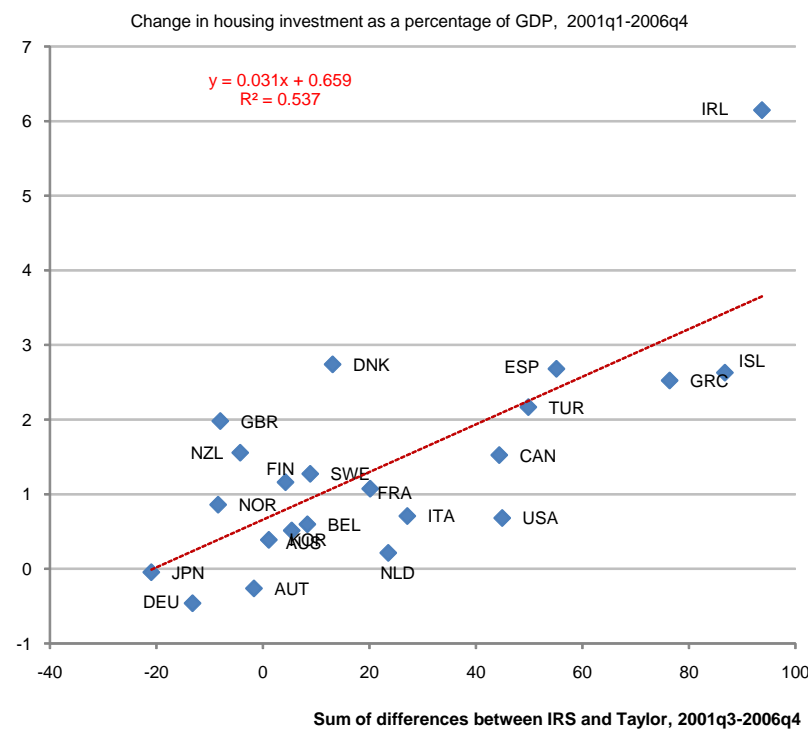

Construction investment versus deviation from Taylor

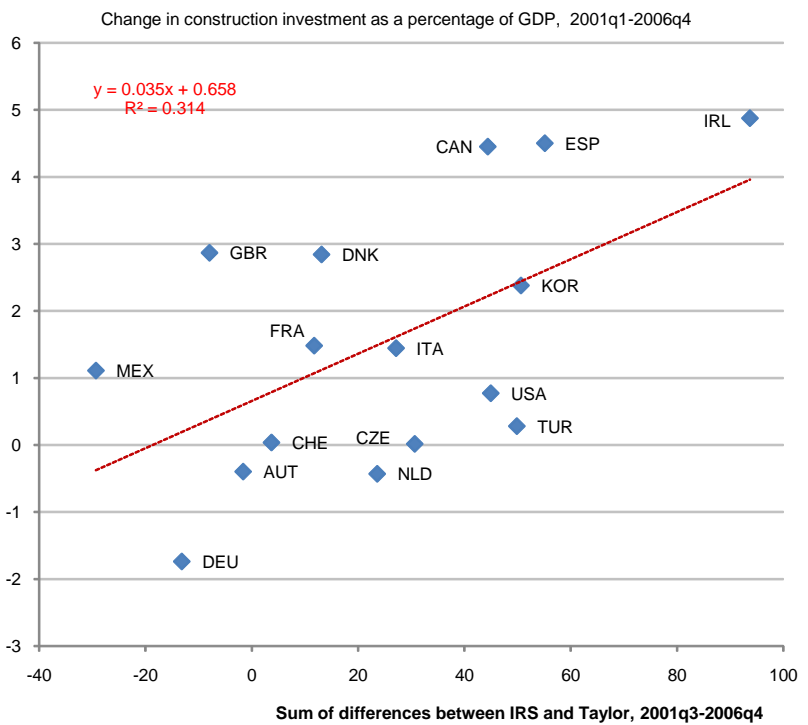

Source: OECD

17. The remainder of this section looks in more depth at episodes where monetary policy has been significantly and consistently below what a simple Taylor rule would have prescribed, investigating the degree to which such episodes coincided with booms in asset prices, and whether those booms resulted in subsequent financial problems, notably in the banking sector. In recent years, policy rates in many countries have been below what a standard Taylor rule would have prescribed. Examples include the United States (2001-06), Canada (2001-07), Denmark (2001-04), and Australia (2000-03). Euro area interest rates were only slightly below what a Taylor rule would have called for, but were well below for some members, i.e. Portugal (1998-2005), Spain (1998-2007), Greece (2000-07), the Netherlands (19982004), Italy (1999-06), Ireland (1999-2007), and Finland (2000-02) (see Figure 5). In addition to these recent episodes of "being below Taylor", there are also some historical precedents, namely Switzerland (1985-88), Finland (1987-89), the United Kingdom (1987-90), and the United States (1990-93). ${ }^{17}$

18. Table 1, which synthesises information concerning the sampled episodes, shows that periods below Taylor seem to be particularly correlated with housing sector buoyancy. Close to $95 \%$ of the episodes saw strong house price increases (and 75\% very strong increases). A similar picture emerges for mortgage credit, total credit to the private sector and, to a slightly lesser degree, housing investment. For monetary aggregates, the evidence is limited and less convincing, whereas equity markets were not systematically affected in a noticeable way.

17. As mentioned earlier, the methodology chosen may be missing some potential historical episodes. This, however, is of lesser concern here, as the main objective is simply to find uncontroversial historical precedents to the more recent episodes. Japan (1995-98) and New Zealand (1986-88) are not classified as episodes, as in both cases Taylor rates were artificially high due to one-off jumps in inflation driven by significant increases in consumption tax. Switzerland (1990-92) is also not classified as an episode, as the Taylor rate was also artificially high, with the increase in inflation being mainly driven by a type of one-off increase in rents, which being de facto indexed to mortgage rates, increased sharply when mortgage rates went up significantly in the aftermath of the late 1980s housing bubble. See for example OECD (1991a) and OECD (1992). 
Table 1. Synthetic information concerning "below-Taylor" episodes

\begin{tabular}{|c|c|c|c|c|c|c|c|}
\hline & & Real House Prices & Housing Investment & Mortgage Credit & Credit to private sector & M2 & Stock Market Indices \\
\hline us & $2001-06$ & Strong increase & Very strong increase (initially) ${ }^{* *}$ & Very strong increase & Very strong increase & Moderate increase & Moderate increase \\
\hline Canada & 2001-07 & Very strong increase & Very strong increase & Very strong increase & Very strong increase & Strong increase & Strong increase \\
\hline Denmark & 2001-04 & Strong increase ${ }^{\star}$ & Very strong increase & Very strong increase & n.a. & Very strong increase & Strong increase \\
\hline Norway & 2004-07 & Very strong increase & Moderate increase & Very strong increase & n.a. & Strong increase & Very strong increase \\
\hline Australia & $\underline{2000-03}$ & Very strong increase & Moderate decrease & n.a. & Very strong increase & Strong increase & Moderate decrease \\
\hline Portugal & $1998-2005$ & n.a. & n.a. & Strong increase & n.a. & n.a. & Strong decrease \\
\hline Spain & 1998-2007 & Very strong increase & Very strong increase & Very strong increase & Very strong increase & n.a. & Strong increase \\
\hline Greece & $2000-07$ & Very strong increase & Very strong increase & Very strong increase & Very strong increase & n.a. & Moderate increase \\
\hline Netherlands & 1998-2004 & Very strong increase & Moderate decrease & Strong increase & Very strong increase & n.a. & Strong decrease \\
\hline Italy & 1999-2006 & Strong increase & Strong increase & Very strong increase & Very strong increase & n.a. & Moderate decrease \\
\hline France & 2001-06 & Very strong increase & Very strong increase & Very strong increase & Strong increase & n.a. & Moderate increase \\
\hline Ireland & 1999-2007 & Very strong increase & Very strong increase & Very strong increase & Very strong increase & n.a. & Moderate increase \\
\hline Finland & $\underline{2000-02}$ & Very strong increase & Strong decrease & n.a. & Strong decrease & n.a. & Very strong decrease \\
\hline US & $1990-93$ & Moderate decrease & Moderate increase & Strong increase & Moderate decrease & Moderate decrease & Very strong increase \\
\hline Switzerland & $1985-88$ & Very strong increase & Very strong increase & Very strong increase & Very strong increase & Strong increase & Very strong increase \\
\hline Finland & $1987-89$ & ery strong increase (initially) & Very strong increase & n.a. & n.a. & n.a. & Very strong decrease \\
\hline UK & $1987-90$ & Very strong increase & Very strong increase (initially) $)^{* *}$ & Very strong increase (initially) $)^{* *}$ & Very strong increase & Moderate increase & Moderate decrease \\
\hline
\end{tabular}

* Strong increase in direct aftermath of episode (not taken into account in calculations)

** Strong decrease starting shortly before end of episode excluded from calculation of period average

Real house price increases (yearly average) between 0 and $4 \%$ are classified as moderate, between 4 and $8 \%$ as strong, and above $8 \%$ as very strong. Decreases are classified correspondingly. Changes in the share of housing investment in GDP (over the whole period) between 0 and $0.5 \%$ of GDP are classified as moderate, between 0.5 and $1 \%$ as strong, and above $1 \%$ as very strong. Decreases are classified correspondingly.

Mortgage credit increases (yearly averages) between 0 and $5 \%$ are classified as moderate, between 5 and $10 \%$ as strong, and above $10 \%$ as very strong. Decreases are classified correspondingly. Credit to the private sector increases (yearly averages) between 0 and $5 \%$ are classified as moderate, between 5 and $10 \%$ as strong, and above $10 \%$ as very strong. Decr. classified correspondingly. Real M2 increases (yearly average) between 0 and $4 \%$ are classified as moderate, between 4 and $8 \%$ as strong, and above $8 \%$ as very strong. Decreases are classified correspondingly.

Real stock market index increases (yearly average) between 0 and $4 \%$ are classified as moderate, between 4 and $8 \%$ as strong, and above $8 \%$ as very strong. Decreases classified correspondingly.

19. It should be noted that the majority of episodes have occurred in the same post-2000 period, in a specific global environment which could have had a common effect on the countries involved. The extent to which earlier historical episodes conform to the general characteristics of more recent episodes is thus important. The following first examines historical episodes that resemble relatively clearly the recent experience, before turning to an episode that stands out.

- Conforming episodes The Swiss (1985-88), Finnish (1987-89) and the earlier part of the UK (1987-90) episodes resemble relatively closely the post-2000 experience. All countries witnessed housing booms, reflected in increases in housing credit, housing investment, and house prices (see Figure 12). There was also some growth in monetary aggregates, though not to a degree that would particularly stand out. Comparable to recent episodes, there is no evidence for a systematic impact on equity markets. Finally, all countries had witnessed relatively extensive financial sector deregulation prior to, and during, the episode ${ }^{18}$ probably to some degree the equivalent of the strong financial innovation of recent years. Both in Finland and Switzerland the end of the property boom put stress on the banking system. But while in Switzerland banking failures remained fairly exceptional, Finland experienced a full-blown banking crisis. ${ }^{19}$

- Atypical episodes The US 1990-93 episode is atypical, being characterised by a combination of credit crunch and recession, very weak, though recovering, housing activity and actual falls in house prices and monetary aggregates (see Figure 10). ${ }^{20}$ All in all, while the possibility that it may have contributed to the dot-com bubble cannot be totally discarded, it would be hard to argue that this episode of deviation from a Taylor rule stored up housing-market problems for the future.

18. See, for example, Honkapohja et al. (1999), Vihriälä (1997), OECD (1988), or OECD (1991b).

19. In Switzerland the banking sector may be particularly resilient to domestic turbulences, given its large share of non-domestic clients. In Finland, the banking crisis may also have, to some degree, been driven by the implosion of the Soviet Union and collapsing terms of trade.

20. For a characterisation of the credit crunch see Bernanke et al. (1991). 
20. There are also a number of cases of credit or housing booms, as well as banking crises, in situations where monetary policy was not below what a Taylor rule would have indicated. Striking examples are Japan in the second half of the 1980s, as well as the United Kingdom since 1997 (Figure 10). While specific reasons probably play an important role in such cases, the UK example points to the role financial innovation may play. This would be in line with a fairly wide body of empirical evidence indicating that financial liberalisation, while beneficial in the longer-term, may initially raise the risk of financial instability. ${ }^{21}$ In a similar vein, the recent strong innovation in financial markets, especially in derivatives and structured credit markets, may have contributed to credit booms, where effects may have been strongest in countries at the forefront of financial innovation, probably including the United States and the United Kingdom.

21. To summarise, the evidence drawn from episodes suggests that "below Taylor" periods have generally been associated with the build-up of financial imbalances in housing markets, ${ }^{22}$ and in some instances in credit markets. In contrast, there is no evidence that these periods had significant influence on equity markets, which seem to be driven much more by global conditions.

22. However, monetary ease is not a necessary condition for imbalances, as they can also emerge during periods of financial deregulation or innovation (as such changes by themselves often strongly boost economic activity), even when rates are at or above those implied by a Taylor rule. This may be seen as a symptom of innovation temporarily boosting the neutral rate -- something the current, simple approach does not allow for. There is also some evidence pointing to particularly increased risk when below-Taylor interest rates coincide with periods of rapid financial innovation and/or deregulation.

23. Moreover, a number of factors beyond the direct control of national central banks may have been important ingredients in the recent turmoil, amplifying the impact of monetary ease (or countering the effects of monetary tightening). As noted above, these factors include, first, the non-monetary drivers of accommodating financial conditions, such as external influences on bond yields, liquidity creation and risk premia. And second, financial innovation was particularly strong in structured credit and other creditconnected derivatives markets, posing new supervisory and regulatory challenges. The following two sections describe the main elements at work.

21. See, for example, Drees and Pazarbasioglu (1995), Hutchinson (2002) or Demirgüç-Kunt and Detragiache (1998).

22. The exception, apparently, is a situation where rates are below Taylor in a combination of a recession and a credit crunch. 
Figure 10. Deviation from Taylor rule versus various measures of activity for selected countries

- Taylor rate

- - Short-term rate

\section{United States}
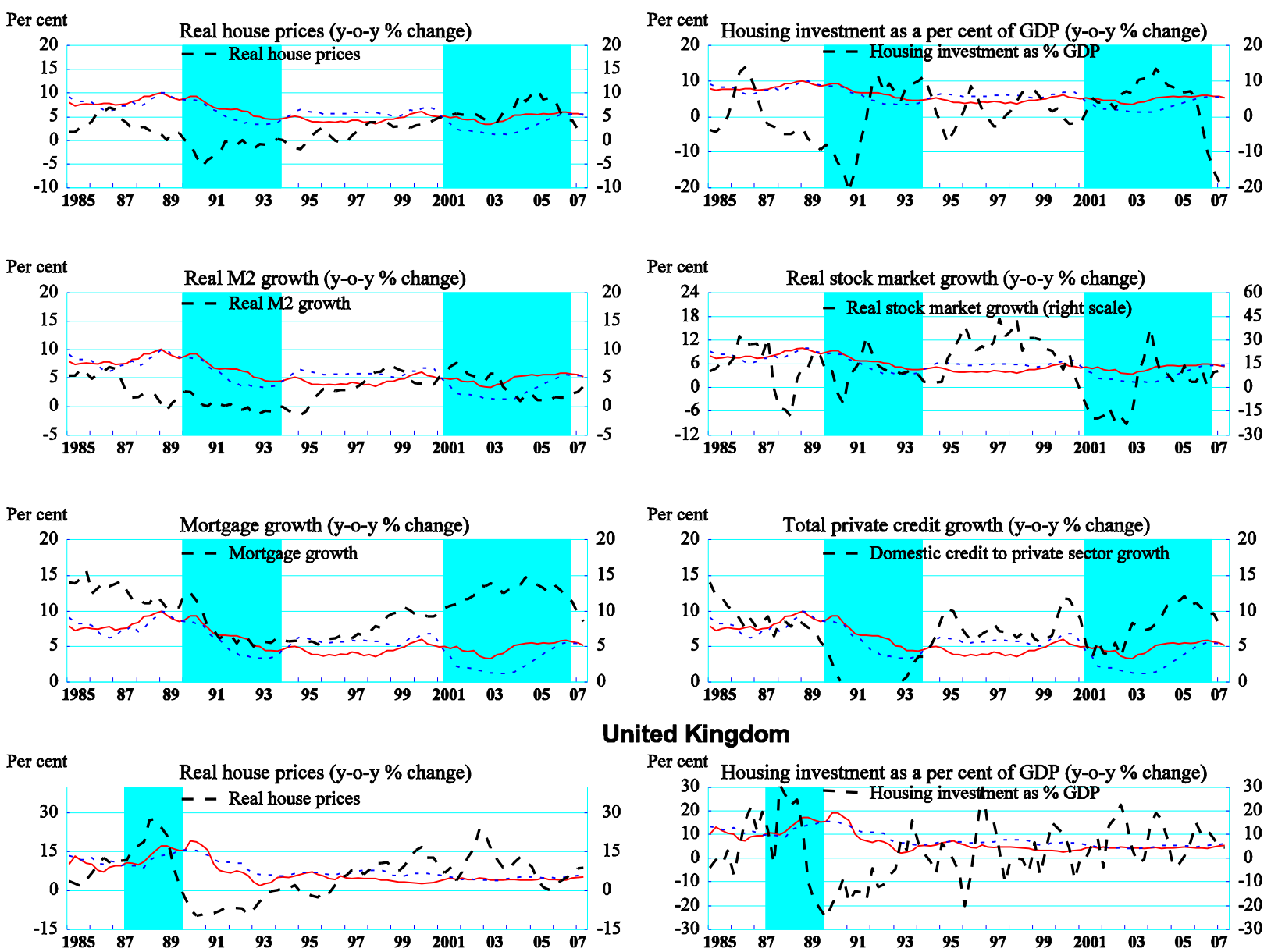

\section{United Kingdom}

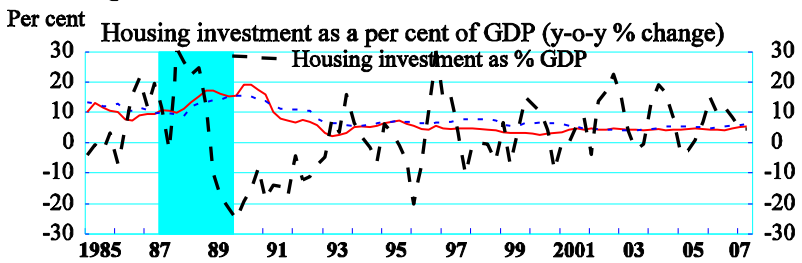
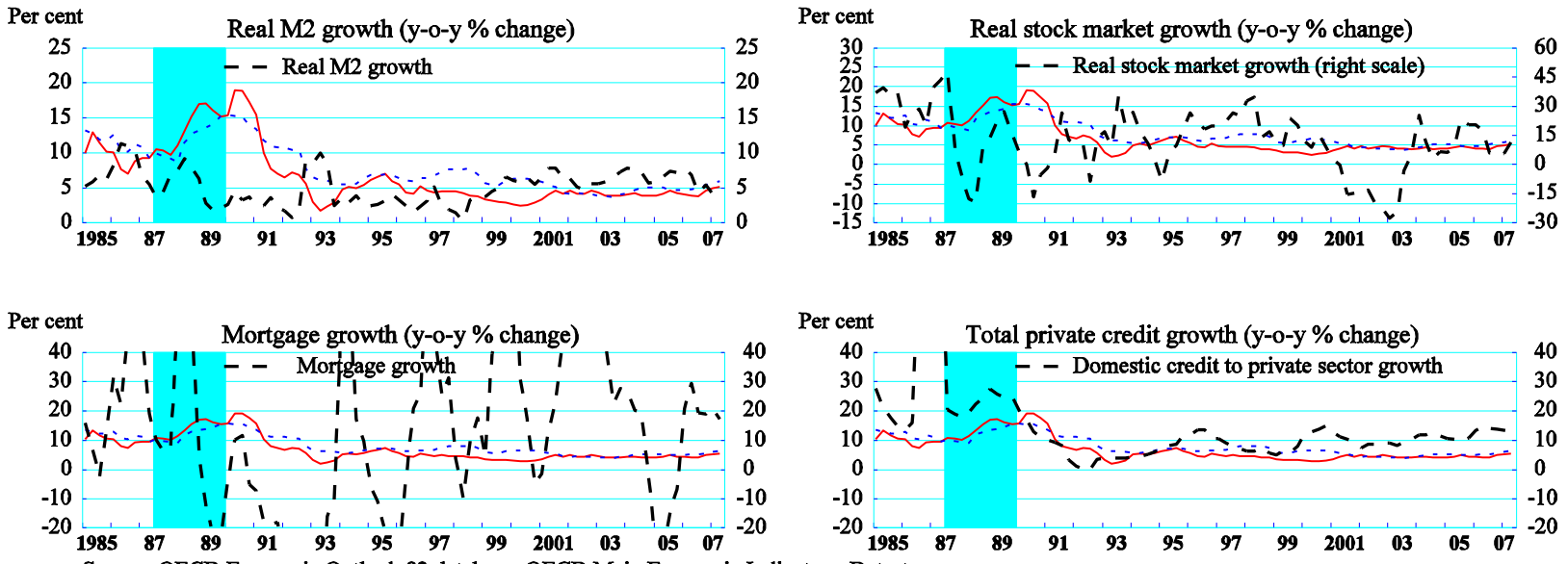
Source: OECD Economic Outlook 82 database; OECD Main Economic Indicators; Datastream. 
Figure 10. Deviation from Taylor rule versus various measures of activity for selected countries (cont.)

- Taylor rate

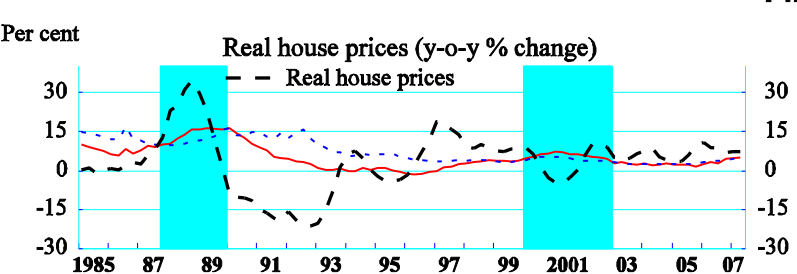

Per cent

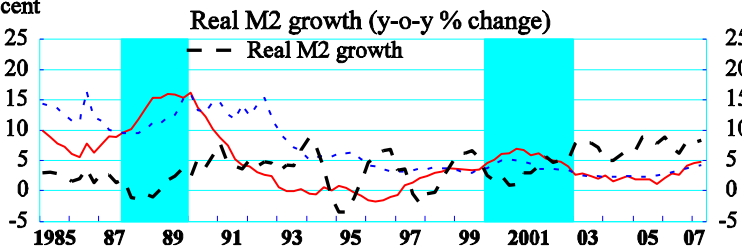

Per cent

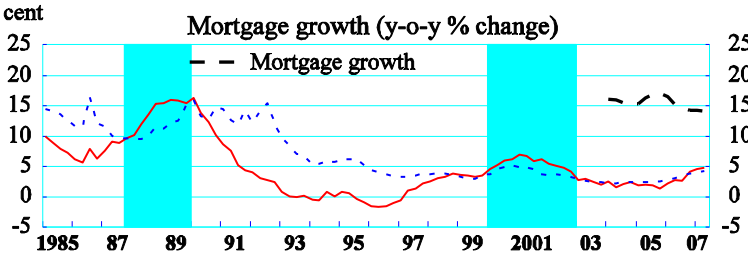

Per cent
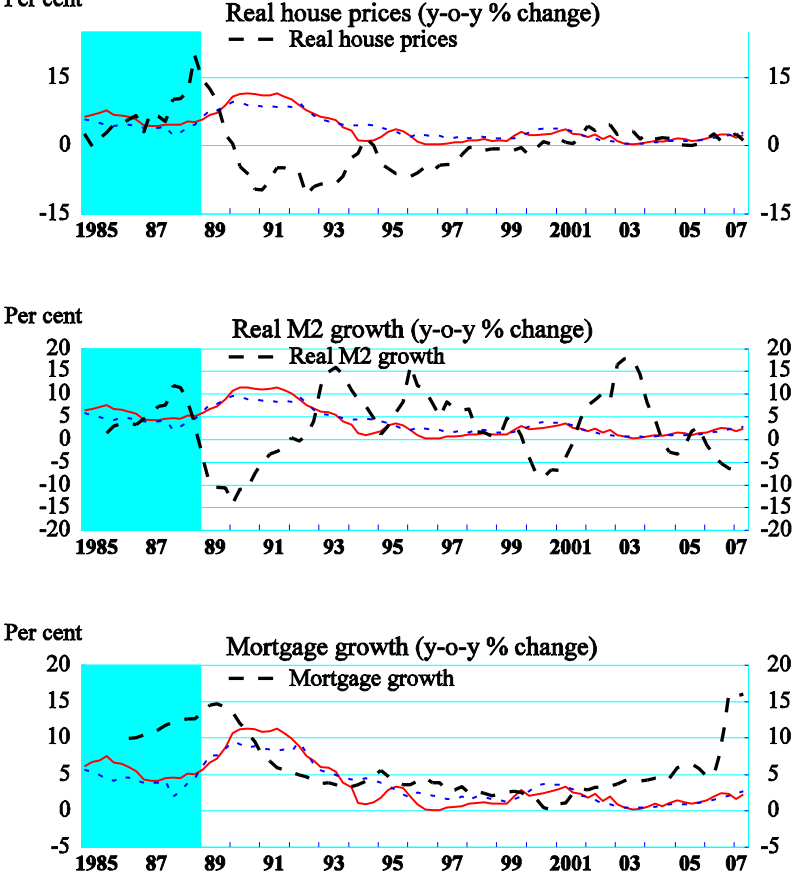

- Short-term rate

\section{Finland}
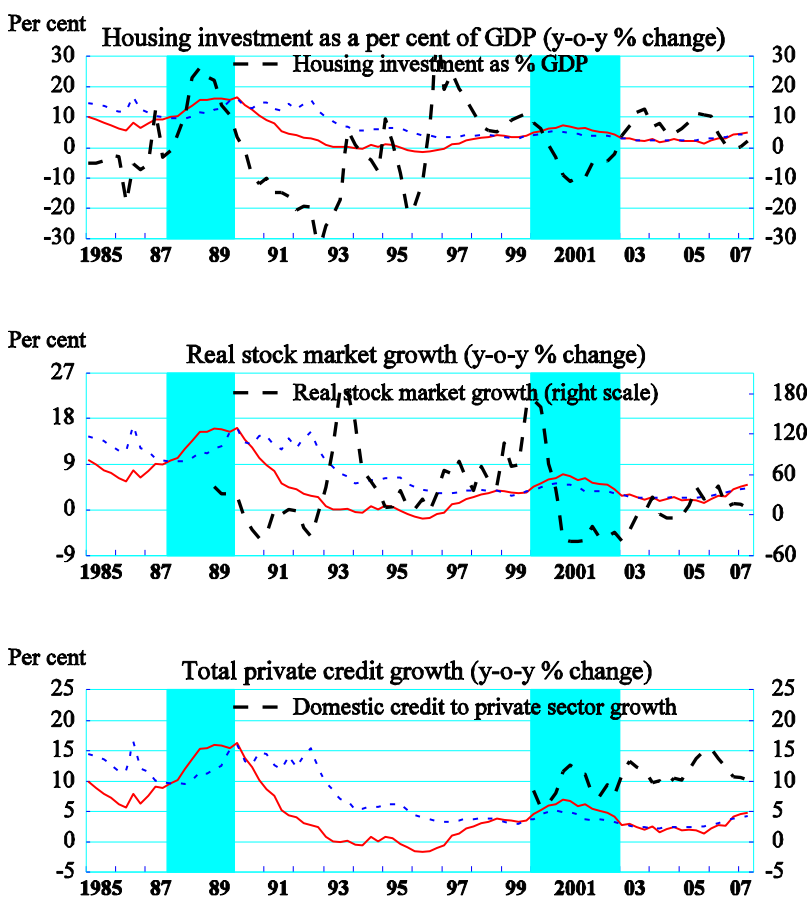

\section{Switzerland}
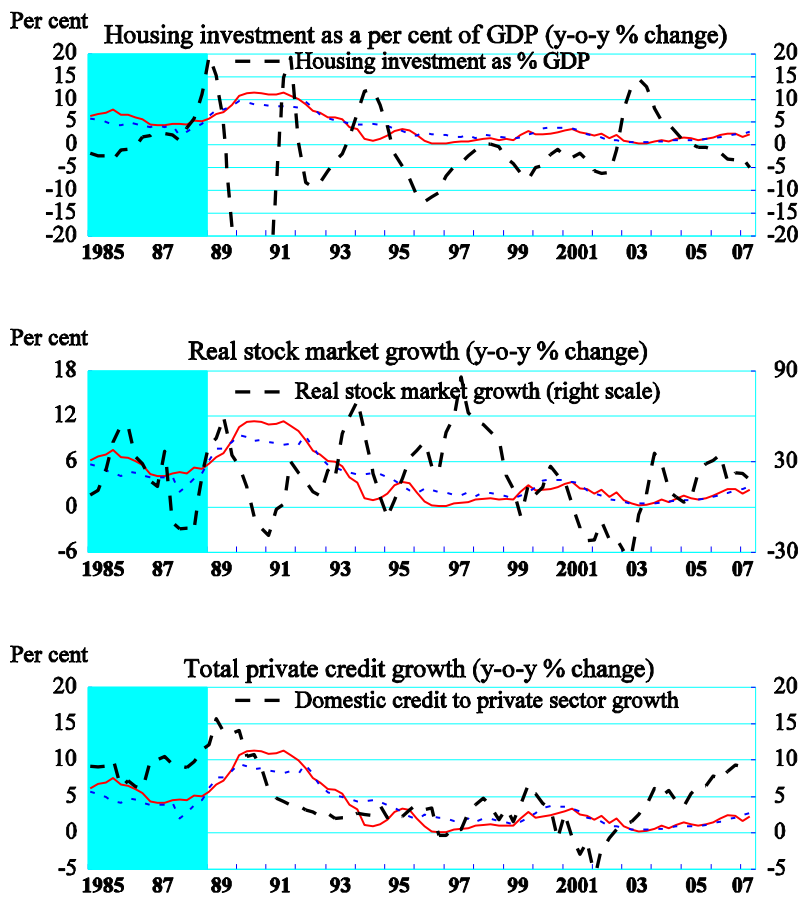
Source: OECD Economic Outlook 82 database; OECD Main Economic Indicators; Datastream. 


\section{Financial market developments and monetary policy}

\section{Low and unresponsive bond yields}

24. In recent years, "risk-free" long-term rates have been low by the standards of previous decades. Monetary policy related factors were, in all likelihood, themselves at play here. In 2002-05, financial market expectations of future average short rates, which should be close to the "neutral" rate, were below what -- at least with hindsight -- would be considered reasonable (Figure 11). Especially in the earlier years, this may have been caused by financial market participants underestimating future inflation pressure (Figure 12). Low long-term rates were in part driven by a number of special factors, beyond OECD central bank control. These include high saving in non-OECD countries combined with strong reserve accumulation by central banks ${ }^{23}$ the emergence of a strong global carry trade which has made it difficult to insulate domestic financial sectors from global influences, reduced interest rate risk due to increased central bank credibility, and, more generally, decreased volatility in real activity and inflation. ${ }^{24}$

\section{Figure 11. United States: bond yields and expected average short rate}

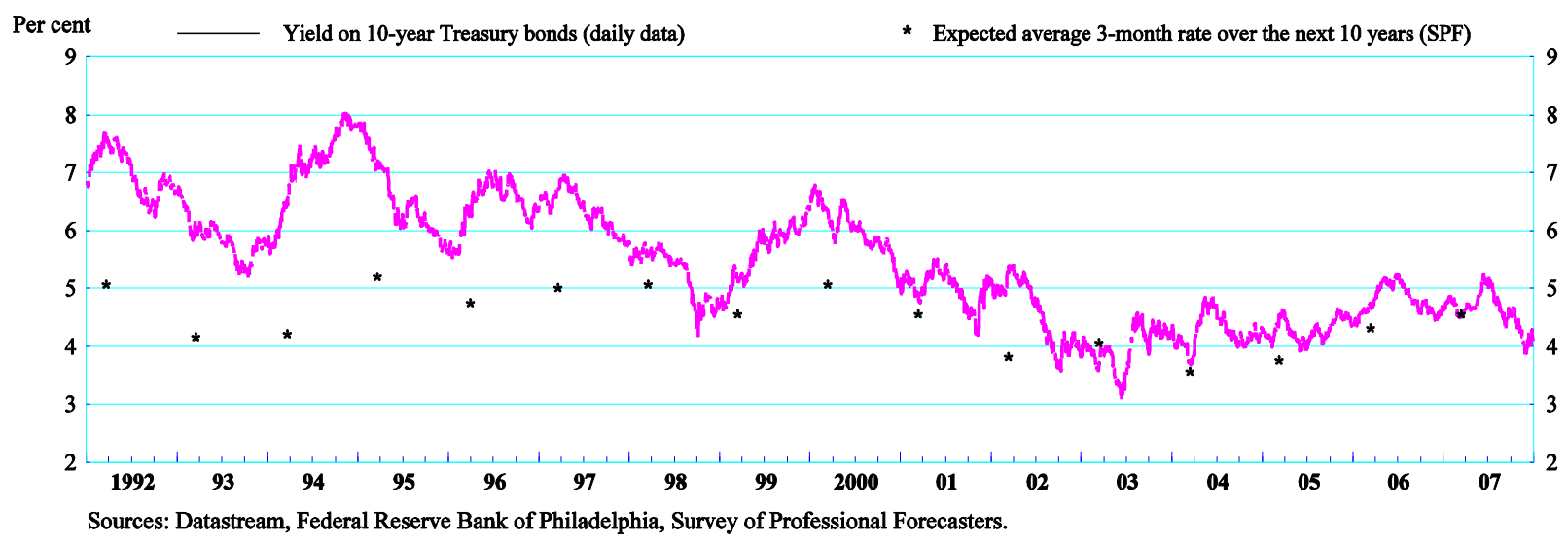

25. In addition to being generally low, long rates have shown less co-movement with changes in policy rates. ${ }^{25}$ Probably the most striking illustration was the failure of US government bond rates to move between mid-2004 and early 2006 in spite of cumulative policy rate increases of 3 percentage points. ${ }^{26}$ The potential reasons for the broad stability of long rates are still controversial, ${ }^{27}$ but this situation resulted

23. Central banks of some emerging economies, as well as oil exporters, have accumulated large reserves in recent years, the largest part being invested in dollar-denominated high grade fixed-income paper.

24. For further discussion of factors behind low long-term interest rates, see e.g. Ahrend et al. (2006).

25. See also Cournède et al. (2008).

26. While the above-mentioned non-monetary factors should mainly influence the level of long rates, they could have mattered insofar as they were strengthening during the period of Federal Reserve tightening, hence counteracting the pressure on long rates from the monetary policy changes.

27. Some observers have argued that the lack of responsiveness of long rates resulted from financial market perceptions of a weaker interest rate response to inflation by the Federal Reserve being a new structural feature. Following Smith and Taylor (2007), in 2003-05 the Federal funds rate significantly deviated from what would have been predicted by the policy response typical over the period since the mid-1980s, with the interest rate response to inflation appearing much lower. This perception could have led markets to expect smaller interest rate responses to inflation in the future, and -- in line with the theoretical model Smith/Taylor present -- smaller responses of long-term interest rate to policy rate fluctuations. 
probably, at least to some degree, from financial markets putting too much weight on the recent past in forming expectations of policy rates, and hence an overly slow adjustment of exaggeratedly low perceptions of neutral rates.

Figure 12. Financial market derived proxies for long-term expected inflation

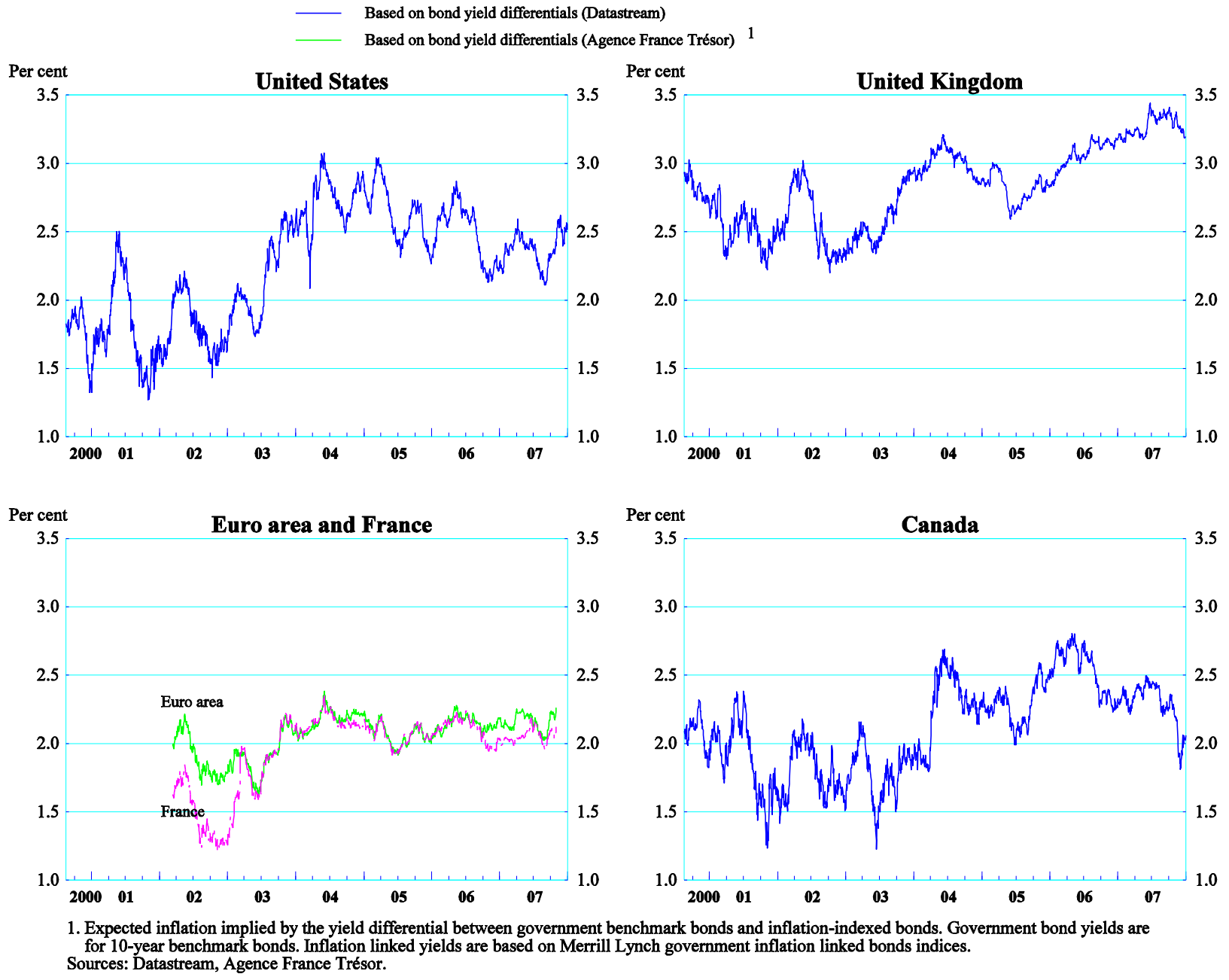

\section{Ample global liquidity conditions}

26. During the past few years, a significant part of liquidity and credit creation has occurred outside the banking system. In analysing global liquidity conditions, it is useful to keep in mind that liquidity is created by any transaction where an agent incurs relatively liquid liabilities (in the sense of being easily useable as, or transferable into, a means of payment, such as money) to buy less liquid assets. This encompasses traditional bank intermediation (borrowing short to lend long), as well as central bank open market operations ${ }^{28}$, but also allows for liquidity creation independently of the banking sector. In analysing

28. Liquidity injections via open market transactions basically consist of central banks handing out IOUs (i.e. money) in exchange for less liquid assets (typically government bonds), hence fitting the broader definition of liquidity creation. 
global liquidity, it is therefore useful to split liquidity into two distinct components: the first is bank-mediated liquidity, typically thought of as proxied by monetary aggregates or measures of credit of the banking to the non-banking sector, and often implicitly referred to when talking about liquidity. Central banks have a certain degree of control over bank-mediated liquidity, which has been abundant in recent years. The second, which may be referred to as "outer liquidity", describes the liquidity creation outside the banking sector, basically depending on the amount of, and ease with which non-banks are willing to extend credit to each other. Central banks' possibilities of control over "outer liquidity" are fairly indirect and probably quite limited, especially in the sense of encouraging its creation in times of financial market pessimism. This may be particularly problematic as recent events would suggest that a large proportion of marginal liquidity is outer liquidity.

27. Bank-mediated and outer liquidity are likely to have acted as complements in recent years: while abundant bank-mediated liquidity was a necessary condition for plentiful outer liquidity, investors' elevated confidence and willingness to take high levels of leverage and risk was also crucial in creating the abundance of outer liquidity that contributed to push up prices in a number of fixed-income related markets. Finally, to the degree that outer liquidity can be influenced by monetary policy, it is likely to depend in large measure on global rather than national policies. As a result, especially in smaller economies or in countries with well developed financial markets, the central bank may have to rely on bolder monetary policy or on additional instruments to influence liquidity conditions, at least for certain periods.

28. Since the onset of the financial market turmoil, all available evidence would point in the direction of a fairly strong contraction in outer liquidity, while it would appear that bank-mediated liquidity has remained relatively abundant. Figure 13 shows that while monetary aggregates have continued to grow at rather solid rates, proxies for elements of outer liquidity, as for example outstanding asset-backed commercial paper, have contracted very sharply. This reinforces the point that central banks' capacity to directly influence outer liquidity, especially in situations of contraction, is fairly limited.

Figure 13. United States -- Outstanding asset backed commercial paper year on year growth rate of monthly data

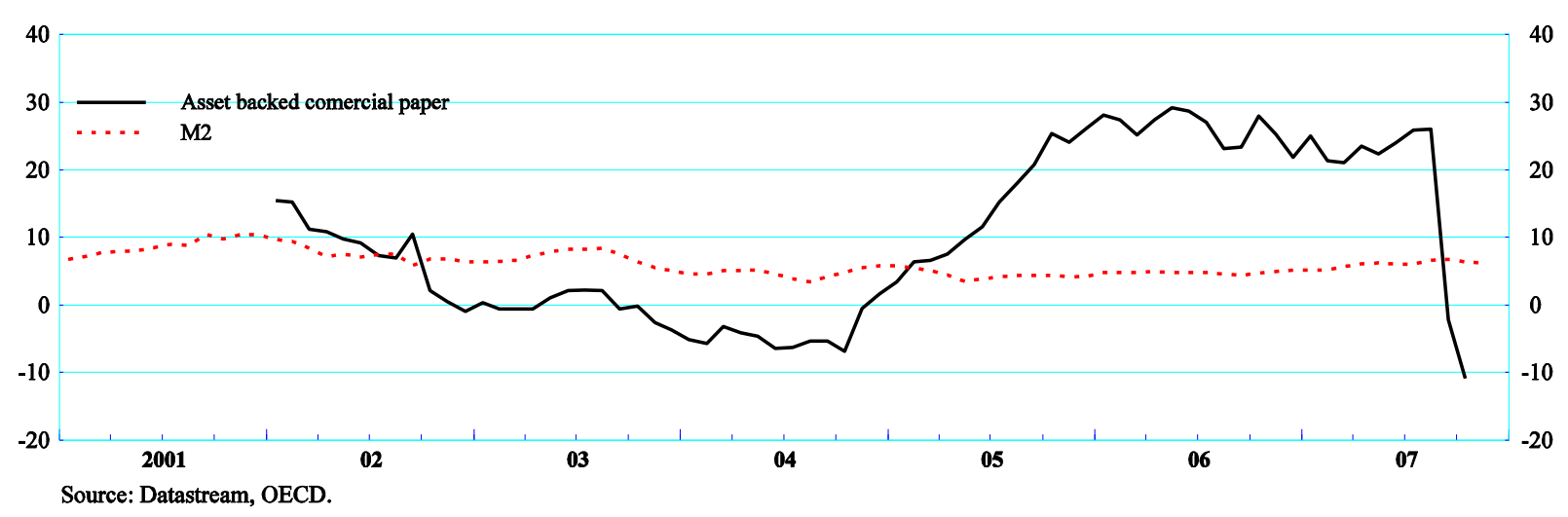

\section{Low volatility, low risk premia and increased risk- taking}

29. Prior to the recent disturbances, the $21^{\text {st }}$ century had been characterised by decreased volatility, both in the real sector and financial markets (Figure 14). Low volatility has been reflected in decreasing 
risk premia for many asset classes, ${ }^{29}$ a tendency that may have been reinforced by an increased predictability of monetary policy. A negative side-effect was that a low volatility environment rewarded -- and hence encouraged -- ever more risk taking, with many investors becoming increasingly complacent about so-called "fat-tail" risk. ${ }^{30}$ The "search for yield" likely also played a role: as traditional investment opportunities could not provide desired returns, the demand for innovative, and inevitably riskier, financial instruments increased, as did leverage, with investors sometimes losing sight of involved risks, driving down risk premia further in the process. To some degree, low risk premia were justified by fundamentals, such as strong corporate balance sheets and improved macroeconomic situations in a number of emerging markets. But low risk premia were also partly a self-feeding phenomenon: compressed risk spreads were justified by very low default risk, with low risk spreads and easy refinancing possibilities being in turn a factor behind low default rates.

Figure 14. United States: Output and inflation volatility

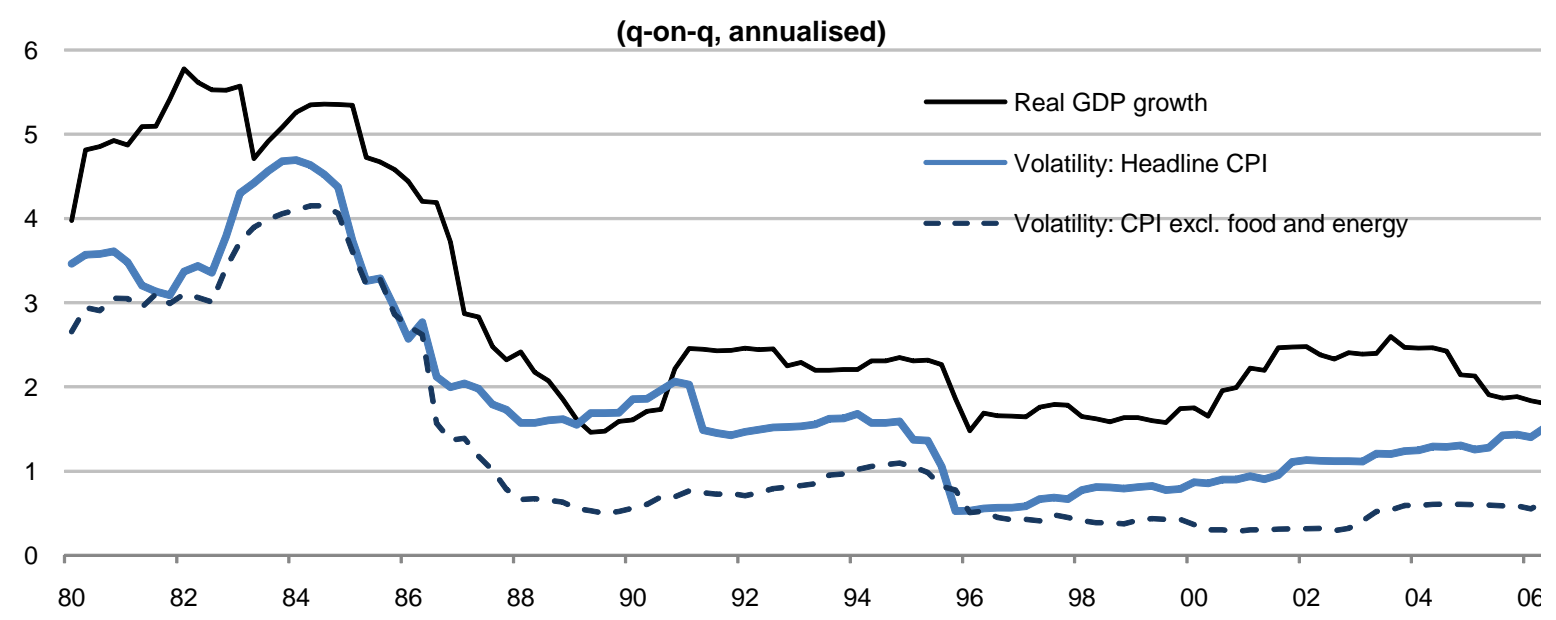

1. Volatility is measured as the standard deviation of quarterly annualised growth over the past 5 years and expressed in percentage terms. Source: OECD Economic Outlook database.

\section{Monetary policy, financial innovation and regulation}

30. In recent years, monetary policy has had to operate within a framework of vibrant financial innovation and -- up to the onset of the current turmoil -- a significant leveraging-up of financial market participants, with both developments affecting monetary policy requirements and outcomes.

\section{Buoyant financial innovation and relaxed regulation}

31. Financial market liberalisation and deregulation is likely to have imparted additional stimulus to economic activity, as has financial innovation more generally. ${ }^{31}$ This implies that during periods where the impact of such legal changes has been large and/or financial innovation particularly strong, all other things

29. Lower volatility could be expected to reduce default risk, and to raise recovery ratios.

30. See Rajan (2006). See also Jimenez et al. (2007) for microeconomically based evidence that low interest rates increase bank risk taking.

31. While financial deregulation/innovation also presents a positive supply shock, in most situations the shock to demand is arguably far larger. 
being equal, monetary policy should have been tighter. ${ }^{32}$ In recent years, financial innovation has been driving a very rapid expansion of derivative markets, with outstanding amounts more than tripling between 2000 and 2006 (Figure 15). ${ }^{33}$

Figure 15. Developments in derivatives markets

Notional value of over-the-counter and exchange-traded derivatives

(Outstanding amounts at year end, as a percentage of nominal OECD GDP)

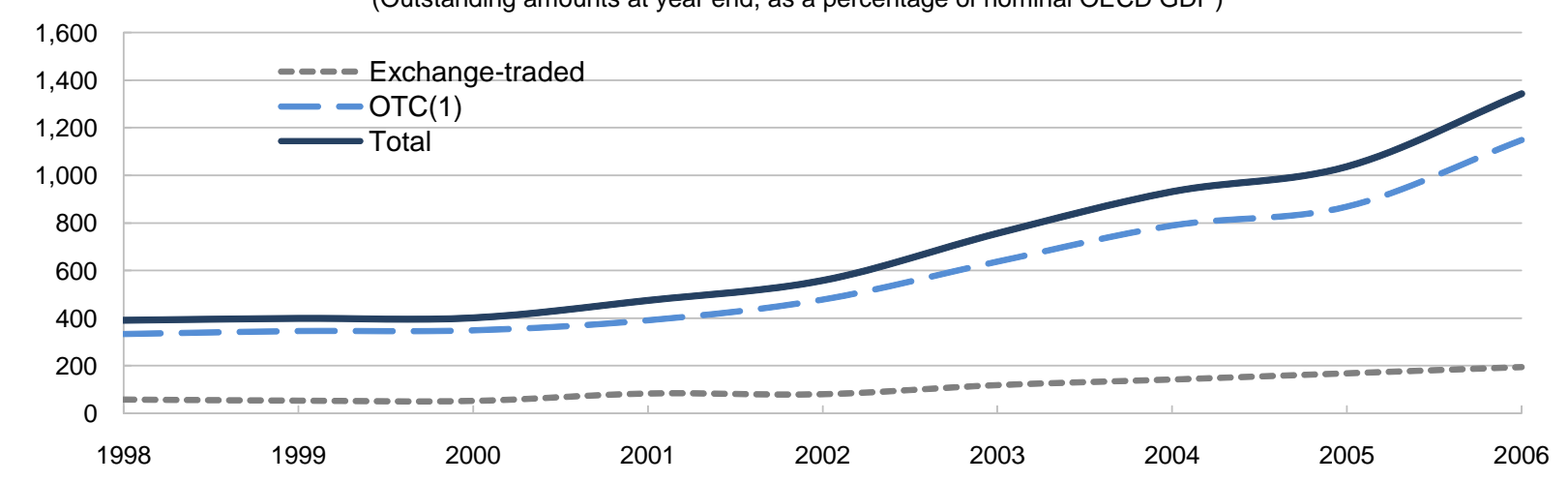

1. OTC derivatives include credit default swaps.

Source: BIS Quarterly Review, September 2007.

32. The elimination of structural barriers between retail and investment banking that resulted from regulatory changes has also implied a much greater fluidity in credit flows from originators of loans to issuers of debt products. For example, securitised assets as a ratio to outstanding bank loans soared to over 45\% in 2006 from somewhat above 25\% in 2000 (Figure 16, Panel A). More recently, markets for more complex loan-based financial products have developed extremely rapidly (Figure 16, Panel B). ${ }^{34}$ These changes have increased the potential for problems to arise in loan markets, as issuers of loans that were meant to be resold have less incentive to ensure loan viability compared with lenders who keep most of the credit risk on their balance sheets.

33. In the United States, this moral hazard problem interacted with lax regulation ${ }^{35}$ and expectations of continuing (even continuous) strong house price inflation, leading numerous agents to solely rely on increasing property values for future re-financing or repayment of loans. Moral hazard problems, more generally, were also stronger when loans were originated by non-banks, as oversight of those entities has often been deficient. Similarly, buyers of loan pools or mortgage-backed securities that intended to repackage them into more complex credit products for reselling, had little incentive to scrutinise the quality of the assets they acquired as long as buyers of the final product cared mainly about its credit rating, and less about the actual quality of the underlying assets.

32. Moreover, the effects may be non-linear, as regulatory loosening or strong financial innovation coupled with accommodative monetary policy may provide a particularly strong boost to economic activity.

33. Financial innovation was in part spurred by the deregulation of the US banking sector, culminating with the repeal of the Glass Steagall Act in 1999. The deregulation also prompted substantial consolidation in the banking sector, resulting in particular in the emergence of a number of banks "too large to fail".

34. The volume of quarterly CDO (Collateralised Debt Obligation) issuance, for example, rose from $\$ 20$ billion to $\$ 160$ billion between early 2004 and early 2007 .

35. In 1999 and 2001, the Federal Reserve issued a set of regulations on sub-prime lending that had the effect of pushing business to lenders that are regulated by the states and the Federal Trade Commission, leading to a highly fragmented system for regulating mortgage lending. 
Figure 16. Developments in structured credit markets

A. Securitised loans

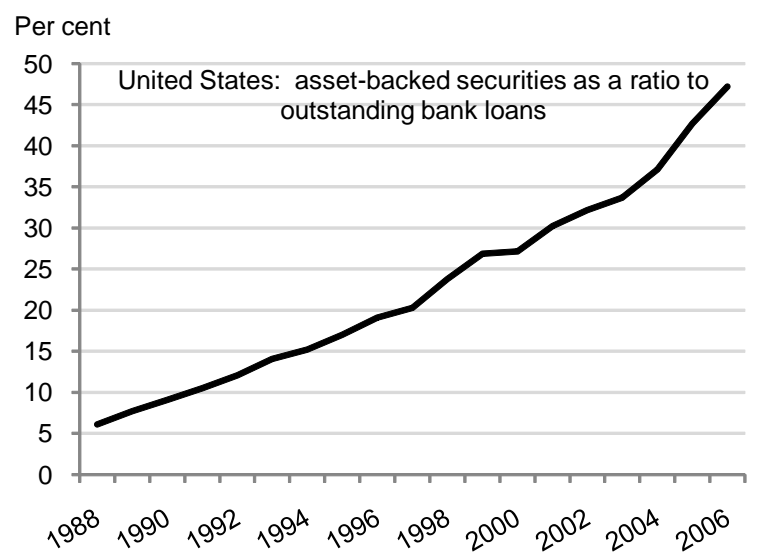

B. Global CDO market issuance

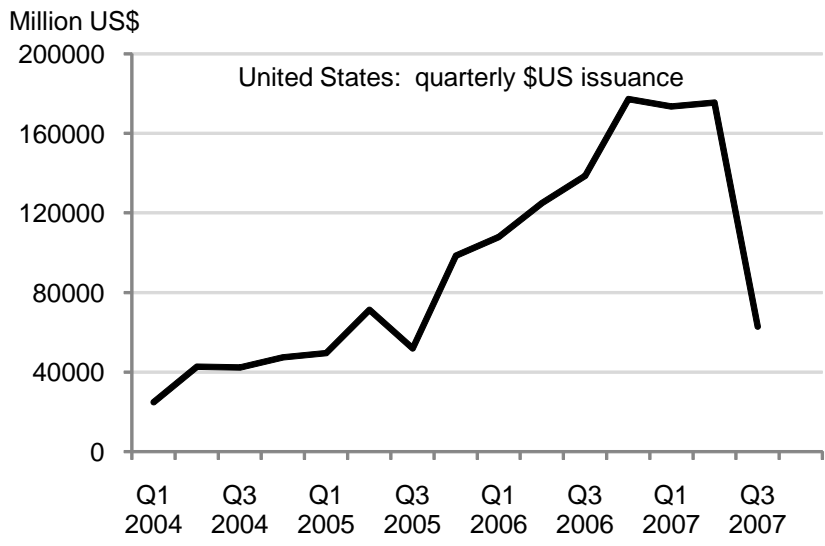

Source: ESF Securitisation Forum; Datastream; OECD calculations; SIFMA.

\section{Expanding off-balance sheet operations}

34. While financial innovation had the favourable effect of potentially reallocating and spreading risk away from the banking system, this came at the price of greater complexity and diminished transparency. Given the strong demand for well-rated, high-yielding paper, even complex synthetic securities could easily be sold to investors who often disregarded risk by relying overly on rating agencies' assessments. In this respect, little attention seems to be given to the fact that rating agencies have no audit requirement, i.e. they simply use the data provided by a prospective issuer for the evaluation of a structured product. Maybe more importantly, rating agencies also face a potential conflict of interest, being paid by deal and deal size, with higher ratings likely to increase the demand for the services of a given rating agency. Possibly as a result, rating agencies used subjective and what in retrospect turned out to be rather optimistic readings of limited historical data when modelling new structured credit products. ${ }^{36}$

35. The possibility to set up off-balance conduits and SIVs, which were not bound by capital adequacy requirements, allowed banks to assume a much higher degree of credit risk. Much of this risk has migrated back to banks' balance sheets in the recent market turmoil, ${ }^{37}$ indicating that better disclosure of banks' off-balance sheet risk, and probably also a larger reflection of those risks in banks' balances, would have been desirable. In this regard, the continued implementation of the Basel II framework will contribute to redress incentives as the exposure arising from committed credit lines will have to be taken into account in the calculation of required capital, though positive effects will hinge on bank models' correct assessment of risk. However, the movement by banks towards off-balance sheet operations may, more broadly, have been a reflection of the unequal regulatory burden on different financial market players, with the more

36. Credit agencies have, at least in the past, been rating credit risk, and not liquidity risk. This may not have been fully understood by investors, but turned out to be crucial when liquidity disappeared.

37. For instance, at one of the largest US banks, balance sheet exposure to CDOs doubled to over $\$ 40$ billion between August and November 2007, as the bank had to honour a series of liquidity commitments. Similarly, at one of the largest European banks, balance sheet exposure to structured finance products rose by $\$ 45$ billion in November, as it consolidated two SIVs on its balance sheet. See Financial Times, 13 and 27 November 2007. 
heavily regulated banks trying to work around the competitive disadvantage more restrictive regulation put them at. ${ }^{38}$

\section{High leverage}

36. A false sense of safety about highly rated, but sometimes not sufficiently understood, new credit products induced and allowed financial market players to leverage to very high levels. ${ }^{39}$ The effects of this leveraging-up were exacerbated by the increasing importance of institutions that tend to rely heavily on leveraging (such as SIVs, conduits, private equity, and most hedge funds ${ }^{40}$ ): assets under management at hedge funds increased 2.5-fold between 2000 and 2006 (Figure 17). Both high leverage and willingness to take on -- sometimes badly understood -- credit risk were factors driving the credit market buoyancy.

Figure 17. Global hedge fund assets

As a percentage of nominal OECD GDP

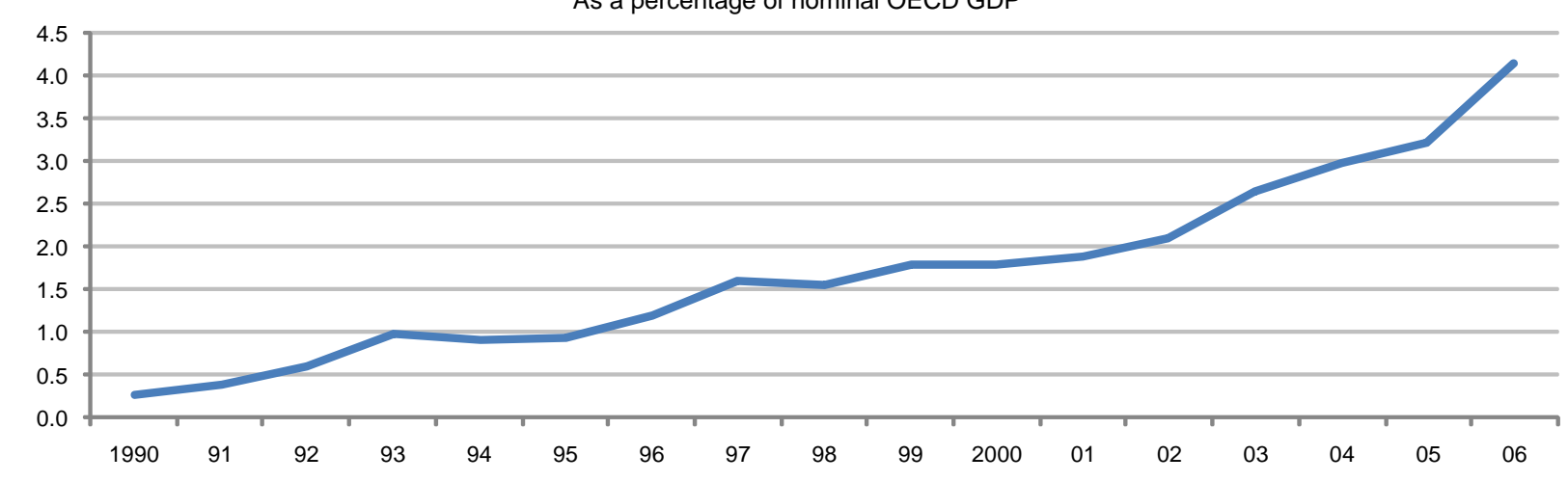

Source: Visco (2007)

\section{Issues relating to the role of monetary policy}

\section{Emerging questions related to inflation targeting}

37. While monetary policy was far from being the only factor in the recent financial-market upheaval, the evidence that it may have contributed raises a number of policy issues. While in the specific circumstances of the early 2000s, deflation risk may have left little alternative than pursuing the actual policies, this constraint may not be binding in future cases where low inflation and monetary ease coincide with rising asset prices leading to financial imbalances that ultimately have to correct. The remainder of this section discusses the possible relevance of asset prices for the conduct of monetary policy, and the appropriateness of monetary policy and non-monetary alternatives to deal with financial imbalances.

38. This, together with the fact that non-bank financial institutions, via their increasing role in liquidity creation, have become systemically important, could be interpreted as pointing to the potential usefulness of some form of enhanced oversight over non-banking financial institutions.

39. While increasing leverage was a general phenomenon, it was particularly visible in leveraged buy-out (LBO) activity. While in the past, large buyouts had often been leveraged at a factor of three times annual earnings, in recent years leverage factors have been sharply increasing. For example, in the United Kingdom, for LBOs above $£ 100$ million, average leverage rose to above a multiple of ten in the first three quarters of 2007. See Financial Times, 5 October 2007.

40. Ironically, hedge funds have so far come out significantly better than banks from the current financial market turmoil. 


\section{Possible relevance of asset prices for monetary policy}

38. Whether, and to what degree, asset price developments should be taken into account when setting policy rates remains a hotly debated issue. An influential view holds that, with respect to monetary policy, asset prices should only be taken into account insofar as they impact on inflation forecasts. ${ }^{41}$ Consequently, inflation targeting as such would be sufficient for achieving price stability, conditional, however, on looking at inflation sufficiently far in the future. ${ }^{42}$ Another line of thought argues that, in practice, forecasting beyond a two-three year horizon is difficult, so looking at asset prices ${ }^{43}$ or a monetary pillar ${ }^{44}$ is potentially useful. Others argue that, independently of the strength of the connection between asset prices and inflation, monetary policy should take into account asset prices insofar as they are signs for the buildup of financial imbalances, with potentially large negative economic consequences. ${ }^{45}$ In this regard, as asset prices are vehicles for intertemporal wealth transfer, and higher asset prices increase the risk of a fall and thereby a reduction in future consumption possibilities, potential losses from increasing asset prices are in this respect similar to losses triggered by inflation.

\section{Appropriateness of monetary policy in combating potential bubbles}

39. The issue of whether and how central banks should react to strong asset price misalignments also remains controversial. One view is that the presence of a bubble can only be established with sufficient certainty once it has burst, and low-cost gradual monetary tightening cannot be relied on for deflating it. As a result it may be argued that central banks should only clean up the fallout from a collapsed bubble ex post. ${ }^{46}$ On the other hand, it may be argued that asset price misalignments are no more difficult to identify than other unobservables regularly relied upon for making monetary policy decisions ${ }^{47}$ and high growth in credit aggregates may be helpful in identifying unsustainable asset price increases. ${ }^{48}$ The recent Australian experience has been cited as a successful example of preventing an asset price boom to get out of hand. ${ }^{49}$ However, monetary policy action is likely to be more useful in the earlier stages of a bubble, because tightening shortly before a bubble bursts can worsen an ensuing economic decline, ${ }^{50}$ but a bubble is particularly difficult to detect in the early stages. In any case, for individual members of a monetary union, or countries with fixed exchange rate regimes, a monetary policy option to fight unwarranted asset price booms upfront does not exist. In these circumstances, the possibility of using monetary policy aggressively in the aftermath of an asset price collapse is also unavailable.

41. Bernanke and Gertler (2001) argue that taking into account asset prices beyond their impact on inflation forecasts may lead to destabilising monetary policy. In contrast, Cecchetti et al. (2002) argue that under more complex monetary rules, reacting to asset prices will usually be stabilising.

42. See Bean (2003) on the need to look at inflation beyond the usual two-three year forecast horizon.

43. See, for example, Cecchetti et al. (2000) or Ingves (2007).

44. See, for example, Trichet (2005).

45. White (2006), for example, strongly advises preventive action against the build-up of financial imbalances.

46. See Greenspan (2002) and Mishkin (2007).

47. Examples would be output gaps, neutral rates, or natural rates of unemployment. See Cecchetti et al. (2000) on this issue.

48. See Borio and Lowe (2004).

49. See, for example, Cecchetti (2005).

50. See, for example, Gruen et al. (2005). 


\section{Potential non-monetary policy options to fight developing financial imbalances}

40. Given the potential limitations or inability of monetary policy in preventing financial imbalances from developing, or in responding once a bubble has burst, the question arises as to whether other policy options are available to national authorities. Drawing the lessons from own and others' experiences can be useful for the prevention of financial imbalances, as varying suboptimal policies or institutional features certainly contributed to unsustainable asset price booms in the past. ${ }^{51}$ In this respect, having sufficiently strict capital requirements in place to allow the banking system to withstand a hit from asset prices is an obvious necessity. Avoiding past errors is, however, only of limited help for genuinely new challenges. Reform of suboptimal structural policies could also be timed so as to lean against strong asset price booms. For example, zoning restrictions could be gradually reduced in a situation of a booming housing market. Such measures, however, are by definition one-offs, and can hence not be a general answer to the question raised.

41. A more systematic attempt at pre-empting the build-up of financial imbalances might involve "macro-prudential" instruments, ${ }^{52}$ the utilisation of which has been controversial and is relatively untested. Macro-prudential measures could include making capital adequacy or reserve requirements dependent on risks of overvaluation of assets, and could be used in a rule-based or more discretionary fashion. A potential problem with capital or reserve requirements is that they would single out the banking sector, and may therefore primarily result in a shift of activity to unregulated non-banking financial institutions. Also, to the degree to which lending is securitised, any measure that works via banks' balance sheets will be a blunt tool. As regards housing, time-variant administrative restrictions of housing credit could be an option, with some observers arguing that restrictions based on borrowers' characteristics are preferable to the above-mentioned measures on lenders. ${ }^{53}$ To be effective and non-discriminatory, such measures should not be restricted to banks, but should apply independently of the type of the lender. Proposed restrictions include making maximum loan-to-value ratios or income coverage ratios depending on measures of potential house price overvaluation. If not already the case, measures of income coverage should be based on long-term rather than short-term rates. Most of the above-mentioned measures are likely to entail some efficiency costs elsewhere, and any implementation should be carefully considered, but especially, though not exclusively, for countries in monetary unions, such costs should be set against the risk of being exposed to financial shocks with no ability to respond through monetary policy. ${ }^{54}$

\section{On the merit of avoiding financial imbalances}

42. While financial crises undoubtedly lead to output losses and social costs, most policies to fight asset price booms imply output or efficiency losses and, possibly, increased deflation risk. ${ }^{55}$ To the extent

51. The recent US housing bubble was probably exacerbated by the lack of a clear and effective institutional set-up for monitoring and regulating activities and incentive structures of non-bank subprime lenders. Other examples of sub-optimal policies contributing to the build-up of financial imbalances include tax laws during the 1980s in some Nordic countries (see, for example, Debelle, 2004).

52. For a detailed discussion of macro-prudential measures see, for example, Borio and White (2004) and references quoted therein.

53. See Cecchetti (2005).

54. Macro-prudential regulation may also help counter regional imbalances in large countries with regulatory possibilities at regional levels.

55. The size of deflation costs remains speculative, but recent research points to mild deflation being relatively benign, as long as it is not accompanied by banking crises or other asset busts (see, for example, Bordo and Filardo, 2005). This does, however, not exclude the risk that, following a large negative shock, mild 
that there is a trade-off, the respective costs and risks would seem important in judging whether paying an "insurance fee" against a possible build-up of financial imbalances is justifiable. Evidence points to houseor property-price collapses being economically more costly than equity crashes, with housing crashes probably having by far the highest social cost. ${ }^{56}$ Though it remains controversial whether there is a case for trying to prevent bubbles from building up, this may at least point to a relatively stronger case for taking out some kind of insurance in the case of property-related booms ${ }^{57}$.

deflation may develop into a deflationary spiral with high economic costs and traditional monetary policy becoming ineffective.

56. Following estimations undertaken at the IMF, post WWII, equity crashes in industrial countries occurred on average every 13 years, lasted four years, and led to GDP losses of around 4\%. House-price, collapses, while less frequent, lasted roughly twice as long with twice as high losses (IMF 2003). Following Cecchetti (2006), equity booms have little impact on the level or volatility of output, but increase the risk of prices falling dramatically below trend. In contrast, housing booms worsen growth prospects, especially as they create large risks of very bad outcomes. Following Detken and Smets (2004), who distinguish between high- and low-cost booms, real-estate price developments would play a larger role in high-cost booms. Other authors, however, see the risk to output from house price booms as fairly limited relative to the effect of other macroeconomic variables. A higher cost of housing than equity crises may in part result from the fact that housing busts have often been associated with banking crises (see Eichengreen and Bordo, 2002), and both fiscal as well as output costs of banking crises have typically been fairly elevated.

57. In that respect it may be worth pointing out that some benefits of interest rates below Taylor may be only temporary anyway, requiring payback later, as an increased contribution of housing to GDP growth during the boom is often followed by a substantial drag on GDP growth from housing in the aftermath of the bust. 


\section{BIBLIOGRAPHY}

Ahrend, R., P. Catte and R. Price (2006), "Factors Behind Low Long-term Interest Rates", Financial Market Trends, pp. 109-141.

Bean, C. (2003), “Asset Prices, Financial Imbalances and Monetary Policy: Are Inflation Targets Enough?”, BIS Working Papers, No. 140.

Bernanke, B., C. Lown and B. Friedman (1991), "The Credit Crunch", Brookings Papers on Economic Activity, Vol. 2, pp. 205-39.

Bernanke, B.S. and M. Gertler (2001), "Should Central Banks Respond to Movements in Asset Prices?", American Economic Review, Vol. 91(2), pp. 253-257.

Bordo, M.D. and A. Filardo (2005), "Deflation in a Historical Perspective”, BIS Working Papers, No. 186.

Borio, C. and P. Lowe (2004), "Securing Sustainable Price Stability: Should Credit Come Back from the Wilderness?”, BIS Working Papers, No. 157.

Borio, C. and W. White (2004), "Whither Monetary and Financial Stability? The Implications of Evolving Policy Regimes", BIS Working Papers, No. 147.

Cecchetti, S.G. (2006), "Measuring the Macroeconomic Risks Posed by Asset Price Booms", NBER Working Papers, No. 12542.

Cecchetti, S. (2005), "The Brave New World of Central Banking: the Policy Challenges Posed by Asset Price Booms and Busts", CNB Working Paper Series, No. 14, Czech National Bank.

Cecchetti, S., H. Genberg, J. Lipsky and S. Wadhwani (2000), "Asset Prices and Central Bank Policy," Geneva Reports on the World Economy, No. 2, Centre for Economic Policy Research, London.

Cournède, B., R. Ahrend, and R. Price (2008), "Have Financial Trends Changed the Transmission of Monetary Policy?", OECD Economics Department Working Papers, forthcoming.

Cotis, J-P, J. Elmeskov and A. Morougane (2004), "Estimates of Potential Output: Benefits and Pitfalls froma Policy Prospective", in L. Reichlin (ed.), The Euro Area Business Cycle, Centre for Economic Policy Research, London.

Debelle, G. (2004), “Macroeconomic Implications of Rising Household Debt”, BIS Working Papers, No. 153.

Demirgüç-Kunt, A. and E. Detragiache (1998), "Financial Liberalization and Financial Fragility", IMF Working Papers, WP/98/83.

Detken, C. and F. Smets (2004), “Asset Price Booms and Monetary Policy”, ECB Working Papers, No. 364. 
Drees, B. and C. Pazarbasioglu (1995), “The Nordic Banking Crises: Pitfalls in Financial Liberalization?”, IMF Working Papers, WP/95/61.

Eichengreen, B. and M.D. Bordo (2002), "Crises now and then: what Lessons from the last Era of Financial Globalization?”, NBER Working Papers, No. 8716.

Girouard, N., M. Kennedy, P. van den Noord, and C. André (2006), "Recent House Price Developments: The Role of Fundamentals", OECD Economics Department Working Papers, No. 475.

Greenspan, A. (2002). "Economic Volatility" in "Rethinking Stabilisation Policy", A Symposium Sponsored by The Federal Reserve Bank of Kansas City, Jackson Hole, Wyoming, 29-31 August.

Gruen, D., M. Plumb, and A. Stone (2005). "How Should Monetary Policy Respond to Asset Price Bubbles?", International Journal of Central Banking, Vol. 1, pp. 1-31.

Hoeller, P. and D. Rae (2007), "Housing Markets and Adjustment in Monetary Union", OECD Economics Department Working Papers, No. 550.

Honkapohja, S., E. Koskela, S. Gerlach and L. Reichlin (1999), "The Economic Crisis of the 1990s in Finland", Economic Policy, No. 29, pp. 399-436.

Hutchinson, M.M. (2002), "European Banking Distress and EMU: Institutional and Macroeconomic Risks", Journal of Economics, Vol. 104, pp. 365-389.

IMF (2003), "When Bubbles Burst”, World Economic Outlook, April.

Ingves, S. (2007), "Housing and monetary Policy -- A View from an Inflation Targeting Central Bank", paper presented at a symposium sponsored by the Federal Reserve Bank of Kansas City, Jackson Hole, September.

Jiménez, G, S. Ongena, J.L. Peydró and J. Saurina (2007), "Hazardous Times for Monetary Policy: What do Twenty-three Million Bank Loans Say about the Effects of Monetary Policy on Credit Risk", CEPR Discussion Papers, No. 6514, October.

King, M. (2007), Speech given at the Northern Ireland Chamber of Commerce and Industry, 9 October, Belfast.

Kohn, D. (2004), "How should Policymakers Deal with Low-Probability, High-Impact Events?", at the European Central Bank Conference on Monetary Policy and Imperfect Knowledge, 15 October, Würzburg, Germany.

Kohn, D. (2007), “John Taylor Rules”, at the Conference on John Taylor's Contributions to Monetary Theory and Policy, Federal Reserve Bank of Dallas, 12 October, Dallas, Texas.

Mishkin, F.S. (2007), "Housing and Monetary Transmission Mechanism”, paper presented at a symposium sponsored by the Federal Reserve Bank of Kansas City, September, Jackson Hole.

Negro del, M. and C. Otrok (2007), "99 Luftballons: Monetary Policy and the House Price Boom across US States”, Journal of Monetary Economics, Vol. 54, pp. 1962-1985.

Noord, P. van den (2006), "Are House Prices Nearing a Peak? A Probit Analysis for 17 OECD Countries", OECD Economics Department Working Papers, No. 488. 
ECO/WKP(2008)5

OECD (1988), OECD Economic Surveys: Switzerland, OECD, Paris.

OECD (1991a), OECD Economic Surveys: New Zealand, OECD, Paris.

OECD (1991b), OECD Economic Surveys: Finland, OECD, Paris.

OECD (1992), OECD Economic Surveys: Switzerland, OECD, Paris.

Pain, N., I. Koske and M. Sollie (2006), "Globalisation and Inflation in the OECD Economies", OECD Economics Department Working Papers, No. 524.

Rae, D. and P. van den Noord (2006), "Ireland's Housing Boom - What has Driven it and Have Prices Overshot?", OECD Economics Department Working Papers, No. 492.

Rajan, R. (2006), "Monetary Policy and Incentives", address delivered at the Bank of Spain Conference on Central Banks, 8 June.

Smith, J. and J. Taylor (2007), "The Long and the Short End of the Term Structure of Policy Rules", Stanford University, September.

Summers, L., (2007), “Beware Moral Hazard Fundamentalists”, Financial Times, 23 September.

Taylor, J. (1993), "Discretion versus Policy Rules in Practice", Carnegie-Rochester Conference Series on Public Policy, Vol. 39, pp. 195-214.

Taylor, J. (2002), "The Role of Exchange Rate in Monetary Policy Rules", American Economic Review, Vol. 91, pp. 263-7.

Taylor, J. (2007), "Housing and Monetary Policy”, paper presented at a symposium sponsored by the Federal Reserve Bank of Kansas City, September, Jackson Hole.

Trichet, J.-C. (2005), “Asset price bubbles and monetary policy”, Mas Lecture, Singapore, 8 June.

Vihriälä, V. (1997), “Banks and the Finnish Credit Cycle, 1986-1995”, Bank of Finland Studies, Vol. E:7.

White, W. (2006), “Is Price Stability Enough?”, BIS Working Papers, No. 205.

Wu, T. (2005), "Estimating the 'neutral' Real Rate in real Time", Economic Research and Data, FRBSF Economic Letter 2005-27. 


\section{WORKING PAPERS}

The full series of Economics Department Working Papers can be consulted at www.oecd.org/eco/Working_Papers/

596. Explaining differences in hours worked among OECD countries: an empirical analysis (February 2008) Sven Blondal and Jean-Marc Burniaux

595. Fiscal policy in India: past reforms and future challenges (February 2008) Richard Herd and Willi Leibfritz

594. The significance of Switzerland's enormous current-account surplus (March 2008) Peter Jarrett and Céline Letremy

593. Interdependencies between monetary policy and foreign-exchange intervention under inflation targeting: the case of Brazil and the Czech Republic

(January 2008) Jean-Yves Gnabo, Luiz de Mello and Diego Moccero

592. Solow or Lucas? Testing growth models using panel data from OECD countries (December 2007) Jens Arnold, Andrea Bassanini and Stefano Scarpetta

591. The private internal rates of return to tertiary education: new estimates for 21 OECD countries (December 2007) Romina Boarini and Hubert Strauss.

590. Making federalism work

(December 2007) Alexandra Bibbee

589. The wage premium on tertiary education: New estimates for 21 OECD countries (December 2007) Hubert Strauss and Christine de la Maisonneuve

588. Enhancing the benefits of financial liberalisation

(March 2007) Stefan Ide, Jens Høj, Patrick Lenain

587. Improving incentives in tertiary education

(March 2007) Jens Høj

586. Globalisation and the European Union: which countries are best placed to cope?

(December 2007) David Rae, Marte Sollie

585. Primary and secondary education in the United States

(November 2007) Peter Tulip and Gregory Wurzburg

584. Financing higher education in the United States

(November 2007) Peter Tulip

583. Corporate net lending: A review of recent trends

(November 2007) Christophe André, Stéphanie Guichard, Mike Kennedy and David Turner

581. Local government finances: The link between intergovernmental transfers and net worth (September 2007) Luiz de Mello 


\section{ECO/WKP(2008)5}

580. Boosting Austria's innovation performance improving innovation (September 2007) Willi Leibfritz and Jürgen Janger

579. Improving employment prospects in the Slovak Republic: Building on past reforms (September 2007) Andres Fuentes

578. Improving education outcomes in the Slovak Republic (September 2007) David Carey

577. Regulatory reforms in Sweden have boosted productivity (September 2007) Espen Erlandsen and Jens Lundsgaard

576. The policy determinants of investment in tertiary education (September 2007) Joaquim Oliveira Martins, Romina Boarini, Hubert Strauss, Christine de la Maisonneuve and Clarice Saadi

575. Product market competition in the OECD countries: taking stock and moving forward (September 2007) Jens Høj, Miguel Jimenez, Maria Maher, Giuseppe Nicoletti, and Michael Wise

574. Too little destruction too little creation: A Schumpeterian diagnosis of barriers to sustained growth in Ukraine

(September 2007) Christian Gianella and William Tompson

573. How do the OECD Growth Projections for the G7 Economies Perform? A post-mortem. (September 2007) Lukas Vogel

572. Austria's deepening economic integration with Central and Eastern Europe (August 2007) Rina Bhattacharya

571. Meeting the challenges of decentralization in France (July 2007) Stéphanie Jamet

Faire face aux défis de la décentralisation en France (juillet 2007) Stéphanie Jamet

570. Enhancing incentives to improve performance in the education system in France (July 2007) Paul O’Brien

Renforcer les incitations à une meilleure performance du système éducatif en France (juillet 2007) Paul O’Brien

569. Combating poverty and social exclusion in France (July 2007) Stéphanie Jamet Lutter contre la pauvreté et l'exclusion social en France (juillet 2007) Stéphanie Jamet

568. The competition law and policy indicator (July 2007) Jens Hoj

567. Structural policies and economic resilience to shocks (July 2007) Romain Duval, Jørgen Elmeskov and Lukas Vogel 